\title{
Artmirasçı Atamada Önmirasçının Taşınmazlara İlişkin Yaptığı Tasarruf İşlemlerinin Geçerliliği Sorunu
}

\author{
Considerations on the Validity of Acts of Dispositions Made by \\ Provisional Heir on Immovable within the context of Appointment of \\ Reversionary Heirs
}

\author{
Gülșah Sinem AYDIN*
}

\section{Öz}

Mülkiyet hakkı sahibine eşya üzerinde tasarruf yetkisi verir. Bu kapsamda malik, mülkiyeti altındaki taşınmaz üzerinde fiilî ve hukukî tasarruflarda bulunabilir. Önmirasçı da mirasın artmirasçıya geçişi anına kadar, miras kapsamında yer alan eşyaların malikidir. Ancak önmirasçının yönetme yetkisinin bir gereği olmaksızın, artmirasçıya devretmekle yükümlü olduğu eşyalar üzerinde, artmirasçının haklarını tehlikeye düşürecek şekilde tasarrufta bulunmaması gerekir. Buna rağmen önmirasçı tasarruf yetkisine dayanarak tasarruf işlemleri yapabilir. Öğretide önmirasçının bu tür tasarruflarda bulunması bakımından tasarruf yetkisinin kısıtlı olup olmadığı tartışmalıdır. Çalışmada önmirasçının, yönetme yetkisi dışında kalan sebeplerle, miras kapsamında yer alan eşyaya ilişkin yaptı̆̆ 1 tasarruf işlemlerinin geçerli olup olmadığı sorunu, taşınmazlar özelinde ele alınacaktır.

Anahtar Kelimeler: Artmirasçı Atama, Önmirasçı, Artmirasçı, Tasarruf İşlemi, Tasarruf Yetkisi.

\begin{abstract}
Ownership grants an owner the authority to make any disposition on his/her assets. In this context, owner is entitled to make any actual and legal disposition on his/her immovable. The provisional heir is the owner of assets being part of the estate, until such estate is vested to the remainderman by operation of law. However, regarding the assets being part of the estate to be vested to the reminderman, the provisional heir should avoid any dispositions that may imperil the rights of the remainderman. In spite thereof, since the provisional heir possesses powers of disposal on such estate, he/she is empowered to perform any act of disposition. According to the scholars' views, it is controversial whether the provisional heir's powers of disposal is limited in terms of making such dispositions, or not. Limited with immovable, the study examines the problem of validity of acts of disposition, which are performed by the provisional heir on assets being part of the estate, excluding any disposition relating to the provisional heir's power of management.
\end{abstract}

Keywords: Appointment of Reversionary Heir, Provisional Heir, Remainderman, Act of Disposition, Powers of Disposal.

Dr. Öğr. Üyesi, Beykent Üniversitesi, Hukuk Fakültesi Medenî Hukuk Anabilim Dalı, sinemaydin@beykent.edu.tr, (ORCID: 0000-0002-0336-6732).. 


\section{GíRiş}

Artmirasçı atama, Türk Medenî Kanunu’nda² m. 521-525 hükümleri arasında düzenlenmiştir. Türk Medenî Kanunu m. 521/I uyarınca artmirasçı atamada mirasbırakan, ölüme bağlı tasarruf yaparak terekesinin tamamı ya da bir kısmı için birden fazla kişiyi art arda mirasçı olarak belirleyebilmektedir ${ }^{3}$. Bu durumda ilk sırada mirasçı sıfatına sahip olan önmirasçı, mirasın artmirasçıya geçişi anına kadar, miras kapsamında yer alan taşınır ve taşınmazlar üzerinde mülkiyet hakkına sahip olduğu için, bu değerleri yönetme yetkisine de sahiptir ${ }^{4}$. Önmirasçı bu yetki uyarınca miras kapsamında yer alan taşınır ve taşınmazları konu alan zorunlu tasarruf işlemlerini yapabilir ${ }^{5}$. Sorun önmirasçının zorunlu olmayan ve artmirasçının haklarını tehlikeye düşürecek nitelikteki tasarruf işlemleri yapması (örneğin taşınmazı üçüncü kişilere devretmesi, taşınmazda sınırlı aynî hak kurması veya kişisel hakları şerh vermesi) durumunda ortaya çıkmaktadır. Söz konusu sorunun çözümü için önmirasçının miras kapsamında yer alan değerler üzerindeki tasarruf yetkisinin kısıtlı olup olmadığının tespiti gereklidir.

Çalışmanın amacı önmirasçının, yönetme yetkisinin gereği dışında kalan sebeplerle, miras kapsamında yer alan taşınmaza ilişkin tasarruf işlemleri yapması halinde, bu tasarrufların geçerli olup olmadığını belirlemektir. Konu itibarıyla önmirasçının miras kapsamında yer alan değerlere ilişkin tasarruf işlemlerinde bulunması çalışmanın iskeletini oluştursa da, çalışmanın kapsamı tasarruf işleminin konusunun taşınmaz mülkiyeti olması hali ile sınırlıdır. Bu nedenle çalışmada önmirasçının ve artmirasçının miras kapsamında yer alan değerleri kazanması ile önmirasçının tasarruf yetkisinin kısıtlı olup olmadığına ilişkin bilgi ve görüşlere çalışmanın kapsamına dâhil olduğu ölçüde yer verilecektir.

Çalışmada ilk olarak önmirasçının (veya önvasiyet alacaklısının) miras kapsamında yer alan taşınmazın mülkiyetini kazanması ve bu kapsamda yerine getirmesi gereken yükümlülükler

2 Kanun No: 4721, Kabul Tarihi: 22.11.2001, Resmî Gazete Tarihi: 08.12.2001, Sayı: 24607, Yürürlük Tarihi: 01.01.2002.

3 Escher, A./Escher, Arnold, Kommentar zum Schweizerischen Zivilgesetzbuch, Das Erbrecht, III. Band, Erste Abteilung: Die Erben (Art. 457-536), Zürich 1959, Art. 488, N. 3, Art. 491, N. 1; Tuor, Peter/Schneyder, Bernhard/ Schmid, Jörg/Rumo-Jungo, Alexandra, Das Schweizerische Zivilgesetzbuch, 13. Auflage, Zürich-Basel-Genf 2009 (Tuor, Peter), \$71, N. 24-25; İmre, Zahit/Erman, Hasan, Miras Hukuku, 14. Basım, İstanbul 2018, s. 150 vd.; Dural, Mustafa/Öz, Turgut, Türk Özel Hukuku, Cilt IV, Miras Hukuku, 12. Bası, İstanbul 2018, N. 791; İnan, Ali Naim/ Ertaş, Şeref/Albaş, Hakan, Türk Medeni Hukuku Miras Hukuku, 10. Bası, Ankara 2019, s. 236; Breitschmid, Peter/ Jungo, Alexandra (Hrsg.), CHK - Handkommentar zum Schweizer Privatrecht, Erbrecht, Art. 457-640 ZGB, 3. Auflage, Zürich 2016 (Hrubesch-Millauer, Stephanie), Art. 488, N. 1; Ayan, Mehmet, Miras Hukuku, 9. Bask1, Ankara 2016, s. 137; Antalya, O. Gökhan/Sağlam, İpek, Miras Hukuku, 3. Baskı, İstanbul 2015, s. 201; Kılıçoğlu, Ahmet, Miras Hukuku, 8. Bası, Ankara 2018, s. 150 vd.; Eren, Fikret/Yücer Aktürk, İpek, Türk Miras Hukuku, Ankara 2019, s. 156.

4 Köprülü, Bülent, Miras Hukuku Dersleri, 2. Bası, İstanbul 1985, s. 191; Dural/Öz, N. 810; Hrubesch-Millauer, Art. 491, N. 6; Kostkiewicz, Jolanta Kren/Wolf, Stefan/Amstutz, Marc/Fankhauser, Roland (Hrsg.), ZGB Kommentar Schweizerisches Zivilgesetzbuch, OFK-Orell Füssli Kommentar, 3. Auflage, Zürich 2016 (Studhalter, Philipp), Art. 491, N. 3; Gürpınar, Damla, Artmirasçı Atama, Ankara 2018, s. 131.

5 Köprülü, s. 196; Gürpınar, s. 137; Mirasbırakanın tereke üzerinde tasarruf etme yetkisine sahip olduğuna ilişkin bkz. Escher/Escher, Art. 491, N. 4; İmre/Erman, s. 157; Dural/Öz, N. 810, N. 815; “... Alelade mirasçı gibi malları iktisap edecek olan davacının, veraset ve intikal vergisi vereceği muhakkak bulunduğuna göre bunu ödemek için veya malların idaresini kolayca yürütülebilmek için, kendisine intikal eden mallar üzerinde temliki tasarrufta bulunması doğaldır. ...", Yarg. HGK, 10.11.1982, E. 1981/2-77, K. 1982/881, legalbank.net (1.04.2019). 
genel itibarıyla ele alınacak, ardından taşınmazın mülkiyetinin artmirasçıya geçmesinin hukukî niteliği belirlenecek ve son olarak önmirasçının miras kapsamında bulunan taşınmaz üzerindeki tasarruf yetkisinin kısıtlı olup olmadığına ilişkin öğretide ileri sürülen görüşler ortaya konarak kanaatimiz açıklanacaktır.

\section{I. Önmirasçının/Önvasiyet Alacaklısının Miras Kapsamında Yer Alan Taşınmazın Mülkiyetini Kazanmasına Genel Bakış}

\section{A. Artmirasçı Atama Tasarrufu Bakımından}

Artmirasçılıkta önmirasçının mirasçılığı vade veya bozucu (infisahî) koşula bağlanırken; artmirasçının mirasçılığı vade veya geciktirici (tâlikî) koşula bağlanmaktadır 6 . Ölüme bağlı tasarrufta mirasın geçiş anı belirtilmemiş ise miras, TMK m. 522/I uyarınca artmirasçıya önmirasçının ölümüyle geçmektedir. Gerek önmirasçı gerekse artmirasçı küllî halef olmakta ${ }^{7}$ ve mirasçılık sıfatını sırayla kazanmaktadır ${ }^{8}$.

Önmirasçı, mirasbırakanın ölmesi ile ilk sırada terekenin tamamı ya da belirli bir kısmı üzerinde doğrudan doğruya hak sahibi olarak mirasçılık sıfatını atanmış mirasçı gibi kazanır 9 (TMK m. 524/I, m. 599). Önmirasçıya geçiş kendiliğinden gerçekleşmekte ${ }^{10}$, artmirasçının mirasçı olması durumunda ise önmirasçının mirasçılık sıfatı sona ermektedir $^{11}$.

6 Escher/Escher, Art. 488, N. 3, Art. 491, N. 1, Art. 492, N. 4; Gönensay, Samim/Birsen, Kemaleddin, Miras Hukuku, İstanbul 1956, s. 148; Oğuzman, M. Kemal, Miras Hukuku, 6. Bası, İstanbul 1995, s. 154; Kocayusufpaşaoğlu, Necip, Miras Hukuku, 3. Bası, İstanbul 1987, s. 291; Köprülü, s. 188-189; Dural/Öz, N. 804; İnan/Ertaş/Albaş, N. 699, N. 710; Hrubesch-Millauer, Art. 488, N. 2,Art. 491, N. 5, Art. 492, N. 8; Serozan, Rona/Engin, Baki İlkay, Miras Hukuku, 5. Baskı, Ankara 2018, $₫$ 4, N. 165a, N. 167; Kılıçoğlu, s. 153; Hausheer, Heinz/Walter, Hans Peter (Hrsg.), Berner Kommentar, Schweizerisches Zivilgesetzbuch, Das Erbrecht, Band III, 1. Abteilung, Die Erben, 1. Teilband, 1. Teil, Art. 457-516 ZGB, Bern 2009 (Weimar, Peter), Vorbem. zu Art. 488, N. 15; Çabri, Sezer, Miras Hukuku Şerhi (TMK m. 495-574) Cilt - I, 1. Baskı, İstanbul 2018, N. 677; Eren/Yücer Aktürk, s. 157, s. 159; Belirtilmelidir ki doktrinde artmirasçı/artvasiyet alacaklısı atama tasarrufunun vadeye veya koşula bağlı bir mirasçı atama niteliğinde olduğu görüşüne karşı çıkan görüşler de bulunmaktadır. Bu görüşler hakkında ileride detaylı bilgi verilecektir. Bkz. Başlık II.

7 Escher/Escher, Art. 488, N. 1, Art. 490, N. 1, Art. 492, N. 2, N. 5; İmre/Erman, s. 157 dn. 18 ; Antalya/ Sağlam, s. 202; Serozan/Engin, \$4, N. 173; Weimar, Art. 489, N. 3, Art. 491, N. 2, Art. 492, N. 8; Aksi yönde görüşle yalnızca önmirasçının küllî halef olduğu, artmirasçının ise vasiyet alacaklısı konumunda bulunduğu, burada bir açıklayıcı tescil/tescilsiz kazanım halinden söz edilemeyeceği, mülkiyetin tescil ile kazanılacağına ilişkin görüş olarak bkz. Hatemi, Hüseyin/Serozan, Rona/Arpacı, Abdülkadir (Hatemi), Eşya Hukuku, İstanbul 1991, s. 560; Aybay, Aydın/Hatemi, Hüseyin, (Hatemi), Eşya Hukuku, 4. Bası, İstanbul 2014, \$11, N. 92-93, \$24, N. 4; Vardar Hamamcıoğlu, Gülşah, Medenî Hukuk’ta Tasarruf İşlemi Kavramı, İstanbul 2014, s. 197.

8 Escher/Escher, Art. 488, N. 3; Hrubesch-Millauer, Art. 488, N. 1-2; Ayan, s. 137-138; Antalya/Sağlam, s. 201-202; Serozan/Engin, $\$ 4$, N. 165.

9 Escher/Escher, Art. 491, N. 1, N. 3; Tuor, § 71, N. 25; İmre/Erman, s. 156; Dural/Öz, N. 807; Weimar, Art. 491, N. 2; Eren/Yüicer Aktürk, s. 159.

10 Escher/Escher, Art. 490, N. 1; Dural/Öz, N. 807; İnan/Ertaş/Albaş, N. 712; Hrubesch-Millauer, Art. 491, N. 1; Ayan, s. 138; Eren/Yücer Aktürk, s. 158.

11 Escher/Escher, Art. 492, N. 6; Köprülü, s. 190-191; Dural/Öz, N. 808. 
Önmirasçı mirasçı sıfatını kazandığı andan itibaren tereke üzerinde hak sahibi olarak kendisine intikal eden eşyaların - çalışma özelinde taşınmazların - malikidir. Ancak önmirasçı, geçiş anı olarak belirlenen vade geldiğinde ya da koşul gerçekleştiğinde bu mirası artmirasçıya geçirme yükümlülüğü altındadır ${ }^{12}$. Miras kapsamında yer alan eşyaların artmirasçıya aynen teslim edilmesi gerekmektedir. Bununla beraber önmirasçının yönetme yetkisi kapsamında yaptığı geçerli tasarruf işlemleri neticesinde eşya terekeden çıkıp, bunun yerini başka bir kaim değer almışsa önmirasçının yükümlülüğü kaim değeri teslim etmek olur ${ }^{13}$.

Dolayısıyla önmirasçının, artmirasçıya intikal edecek olan eşyalara ilişkin, artmirasçının haklarını zedeleyecek şekilde tasarrufta bulunmaması gerekir. Yine de önmirasçı bu değerler üzerinde mülkiyet hakkına sahip olduğundan, kanun koyucu onun bu tür tasarruflarda bulunabileceğini gözeterek, artmirasçının beklenen hakkını güvence altına almak amacıyla TMK m. 523'de çeşitli önlemlerin alınmasına ilişkin düzenleme getirmiştir ${ }^{14}$. Hüküm kapsamında getirilen önlemler, mirasın resmî defterinin tutulması, mirasın önmirasçıya tesliminin güvenceye bağlanması ve mirasın resmen yönetilmesidir.

Önlem olarak ilkin, TMK m. 523/I uyarınca önmirasçıya geçen mirasın sulh mahkemesince defteri tutulur. Bu önlem, artmirasçıya geçecek olan malvarlığının, önmirasçının malvarlığına karışmamasını sağlar ve artmirasçıya geçişini güvence altına alır. Bu sayede artmirasçıya geçecek malvarlığının durumu, miktarı ve bu malvarlığı üzerinde yapılan tasarruflar tespit edilebilir. Böylece önmirasçının artmirasçıdan mal kaçırması da önlenmekte ve ayrıca artmirasçıya ispat kolaylığı sağlanmaktadır ${ }^{15}$.

Türk Medenî Kanunu m. 523/II’ye göre mirasın önmirasçıya teslimi, önmirasçının güvence göstermesine bağlıdır. Mirasın artmirasçıya geçişi anında önmirasçı ölmüşse, onun mirasçları güvence göstermekle yükümlü olur (TMK m. 522/II). Güvence gösterilmesi, mirasın önmirasçıya fiilen teslimi, miras kapsamında yer alan taşınmazlar özelinde ise açıklayıcı tescilin yapılması için bir zorunluluktur. Söz konusu zorunluluğun getirilmesi ile amaçlanan, mirasın artmirasçıya geçişini teminat altına almak ${ }^{16}$, doğrudan geçişin sağlanamaması halinde ise artmirasçının bu nedenle uğradığı zararı tazmin etmektir ${ }^{17}$. Ancak önmirasçının güvence göstermemesi onun

12 Escher/Escher, Art. 491, N. 1, Art. 491, N. 4; Saymen, Ferit H., Miras Hukuku Dersleri, İstanbul 1955, s. 136-137; Dural/Öz, N. 808, N. 811, N. 815; Hrubesch-Millauer, Art. 491, N. 3, N. 5; Weimar, Art. 491, N. 1, N. 5, Vorbem. zu Art. 488, N. 8, N. 16; İşü̈zar, Hasan/Demir, Mehmet/Yılmaz, Süleyman, Miras Hukuku, Ankara 2019 , s. 70.

13 Escher/Escher, Art. 492, N. 10-11; Tuor, $\$ 71$, N. 25; İmre, Zahit, Türk Miras Hukuku, 3. Bası, 1972, s. 207; Dural/ Öz, N. 811; Weimar, Art. 491, N. 7; Eren/Yücer Aktürk, s. 159.

14 Escher/Escher, Art. 490, N. 2; Hrubesch-Millauer, Art. 490, N. 1; Ayan, s. 138; Kılıçoğlu, s. 151.

15 Escher/Escher, Art. 490, N. 2-3; İmre/Erman, s. 158; Dural/Öz, N. 815; Hrubesch-Millauer, Art. 401, N. 2; Studhalter, Art. 490, N. 1; Mirasın resmî defterinin tutulmasında, intikal eden malların değerinin de gösterilmesi gerektiği, böylece gösterilecek güvencenin miktarının da belirlenebileceği yönünde bkz. Gürpınar, s. 178; Çabri, N. 694.

16 Escher/Escher, Art. 490, N. 2; Ünal, Mehmet/Başpınar, Veysel, Şeklî Eşya Hukuku, 9. Baskı, Ankara 2017, s. 361; Dural/Öz, N. 815; Hrubesch-Millauer, Art. 490, N. 1; Antalya/Sağlam, s. 203.

17 Escher/Escher, Art. 490, N. 2; Weimar, Art. 490, N. 9. 
mirasçı sıfatını kazanmasına engel olmaz. Güvence gösterilmemesi mirasın önmirasçıya fiilen teslim edilmesini engellemektedir. Ayrıca önmirasçı tarafından güvence gösterilmezse ya da gösterilmekle beraber gösterilen güvence yeterli olmazsa ${ }^{18}$, sulh mahkemesi önmirasçının miras payının resmen yönetilmesine karar verir ${ }^{19}$ (TMK m. 523/III).

Güvencenin çeşidi bakımından TMK m. 523/II'de bir sınırlama getirilmediği için, çeşitli şekillerde güvence gösterilebilir. Bu kapsamda verilen güvencenin rehin, kefalet, banka teminat mektubu, kıymetli evrak gibi aynî veya şahsî nitelikte olması mümkündür²0. Ayrıca TMK m. 523/ II uyarınca taşınmazlar bakımından güvence şerh verilmesi yoluyla da yapılabilir. Önmirasçının mirası geçirme yükümlülügünün tapu kütügüne şerh verilebileceği gerek TMK m. 523/II ve TMK m. 1010/b. 3'de gerekse TST m. 48/(1)/b'de belirtilmiştir.

Miras kapsamında yalnızca taşınmaz bulunuyorsa güvence olarak sadece şerh verilmesi mümkündür. Buna karşılık taşınmazın yanı sıra miras kapsamında başka değerler varsa, şerhe ek olarak diğer güvence çeşitlerine de başvurulabilir ${ }^{21}$. Öte yandan taşınmaz bakımından güvence yerine geçmek üzere tapu kütügüne şerh verilmesinin zorunlu olup olmadığg hususu öğretide tartışmalıdır. Bu tartışma kapsamında önmirasçının artmirasçıya şerh dışında güvence sağlamasına rağmen, artmirasçının yine de şerh verilmesini isteyip isteyemeyeceği ele alınmaktadır. Hâkim görüş bu hususta önmirasçının tercih yaparken özgür olduğunu, miras kapsamında taşınmaz olsa bile, güvence çeşitlerinden şerh verme yoluna başvurmasının zorunlu olmadığını, güvenceyi ister şerh yoluyla isterse başka bir güvence çeşidine başvurarak sağlayabileceğini kabul etmektedir. Ancak bu konuda mirasbırakan tarafından bir sınırlama getirilerek, taşınmazlar bakımından tapu kütüğüne şerh verilmesi zorunlu tutulabilir ${ }^{22}$. Buna karşılık diğer görüşe göre mirasbırakanın aksi yönde bir iradesi yoksa artmirasçı şerhten başka bir güvence gösterilmesine razı olmadıkça, önmirasçı taşınmazlar için şerhin dışında diğer bir güvence çeşidine başvuramamalıdır ${ }^{23}$.

Kanımızca hükmün lafzı önmirasçının bu konuda seçim hakkına sahip olduğu sonucuna götürmektedir. Ancak hükmün bu hali ile uygulanmasının gerek artmirasçı atama tasarrufunun

18 Hükümde miktar konusunda bir sınırlama getirilmiş olmamakla birlikte, işin niteliği gereği gösterilecek güvence, artmirasçının beklenen hakkını koruyacak miktarla orantılı olmalıdır, Escher/Escher, Art. 490, N. 7; Honsell, Heinrich/Vogt, Nedim Peter/Geiser, Thomas (Hrsg.), Basler Kommentar, Zivilgesetzbuch II, Art. 457-977 ZGB, Art. 1-61 SchlT ZGB, 3. Auflage, Basel/Genf/München 2007, Art. 490, N. 4; Studhalter, Art. 490, N. 4; Çabri, N. 697; Eren/Yücer Aktürk, s. 158.

19 Escher/Escher, Art. 490, N. 9; Dural/Öz, N. 822; Hrubesch-Millauer, Art. 490, N. 12; Weimar, Art. 490 , N. 23. Escher/Escher, Art. 490, N. 6; Köprülï,, s. 193; Dural/Öz, N. 820; Ayan, s. 139; Weimar, Art. 490, N. 13.

Escher/Escher, Art. 490, N. 8; Hrubesch-Millauer, Art. 490, N. 10; Gürpınar, s. 189

Escher/Escher, Art. 490, N. 8; Gönensay/Birsen, s. 151; Gürsoy, Kemal Tahir, Türk Medenî Kanunu Hükümlerine Göre Mal Vasiyeti, Ankara 1955, s. 179; Dural/Öz, N. 820; Hrubesch-Millauer, Art. 490, N. 10; Honsell/Vogt/ Geiser, Art. 490, N. 4; Doğan, Murat, Tapu Sicilinde Tasarruf Yetkisi Kısıtlamasının Şerhi, Ankara 2004, s. 83; Weimar, Art. 490, N. 14; Gürpınar, s. 189.

23 Homberger, A., Kommentar zum Schweizerischen Zivilgesetzbuch, IV. Band: Sachenrecht, 3. Abteilung, Besitz und Grundbuch, Art. 919-977, 2. Auflage, Zürich 1938, Art. 960, N. 44; Kanunda güvenceye ilişkin hüküm artmirasçının lehine olarak konulduğuna göre, bu hükmün artmirasçının lehine kullanılması gerektiği, bu nedenle kanun koyucunun amacına uygun olarak artmirasçı tarafından da şerhin talep edilebileceği görüşünde İmre, s. 209. 
amacı gerekse mirasbırakanın iradesi ile örtüşmediği kanaatindeyiz. Şöyle ki; artmirasçı atamada mirasbırakanın iradesi, miras kapsamında yer alan değerlerin geçiş anının gelmesi ile beraber önmirasçı tarafından artmirasçıya geçirilmesine yöneliktir. Nitekim Türk Medenî Kanunu'nda önmirasçı bakımından bu değerleri artmirasçıya geçirme yükümlülüğü (m. 524/II) ve artmirasçının haklarının teminat altına alınması amacı ile güvence gösterme yükümlülügü (m. 523/II) getirilmiştir. Dolayısıyla gerek artmirasçı atama tasarrufunun amacından gerekse mirasbırakanın iradesinin yorumundan, mümkün olduğunca artmirasçıya miras kapsamında yer alan değerleri aynen aktaracak korumayı sağlamanın istendiği anlaşılmaktadır. Taşınmazlar bakımından taşınmazın aynen artmirasçıya devrini sağlayacak yegâne korumanın ise şerh olduğu açıktır ${ }^{24}$. Zira ileride detaylı olarak açıklayacağımız üzere ${ }^{25}$ şerhin verilmesi ile önmirasçının bundan sonraki tasarrufları artmirasçıya karşı ileri sürülemez hale gelmektedir. Buna göre şerhten sonra önmirasçı taşınmazı bir üçüncü kişiye devretse de TMK m. 1010/ II uyarınca artmirasçı bu kişiye karşı yönelteceği tapu sicilinin düzeltilmesi davası ile (TMK m. 1025) taşınmazın kendi adına tescilini sağlayabilir. Taşınmazlar bakımından önmirasçının göstereceği diğer güvencelerin ise, şerh kadar taşınmazın artmirasçıya devrini güvence altına almayacağı açıktır ${ }^{26}$. Diğer güvencelerin gösterilmesi durumunda önmirasçı taşınmazda dilediği tasarrufu yapabilir ve artmirasçı geçiş anı geldiğinde taşınmazın aynına kavuşamayıp yalnızca zararını istemek durumunda kalabilir. Bu nedenle kanımızca kural olarak artmirasçı atamada önmirasçı her türlü güvenceyi gösterebilirse de, artmirasçının talep etmesi halinde tapu siciline şerh yoluna başvurulmalıdır. Bize göre de lege ferenda bir öneri olarak kanunda güvencenin çeşidi bakımından tercih özgürlüğü artmirasçıya bırakılmalı, ayrıca şerhin yanı sıra diğer güvencelerin de gösterilebilmesine açıkça imkân tanınmalıdır. Nitekim çoğu zaman taşınmazlar bakımından yalnızca şerh yeterli bir koruma sağlamayabilir ${ }^{27}$. Önmirasçı taşınmaza malik olduğu süreçte taşınmazda değer kaybına yol açacak durumlar meydana gelebilir. Örneğin önmirasçının kendisi ya da şerhin konmasından sonra önmirasçının taşınmazı devrettiği üçüncü kişi taşınmaza zarar verirse şerh bu zararların karşılanmasını sağlamaz. Dolayısıyla taşınmazlar söz konusu olduğunda şerhin yanı sıra diğer güvence çeşitlerine de başvurulması artmirasçının yararına olacaktır ${ }^{28}$.

24 Şerhin taşınmazlarda önmirasçı tarafından artmirasçının haklarının ihlâl edilmesi bakımından geniş ve kapsamlı bir koruma sunduğu yönünde Escher/Escher, Art. 490, N. 8; Hrubesch-Millauer, Art. 490, N. 10.

25 Bkz. Başlık III., B.

26 Şerhin taşınmazın aynının artmirasçıya devrini güvence altına aldığına ilişkin bkz. Piotet, Paul, Schweizerisches Privatrecht, Vierter Band, Erbrecht, Erster Halbband, Basel 1978, s. 118; Honsell/Vogt/Geiser, Art. 490, N. 4; Gürpınar, s. 190.

27 Aynı yönde şerhin, yalnızca artmirasçıya taşınmazın aynının devrini güvence altına alacağı, ancak önmirasçının ya da taşınmazı ondan edinen kişinin kusuru ile taşınmazda ortaya çıkabilecek değer azalmalarını karşılamayacağına ilişkin bkz. Gürpınar, s. 189-190; Artmirasçının şerhin yanı sıra ek güvence ihtiyacının bulunduğu yönünde Piotet, s. 118; Aksi yönde taşınmazlar bakımından şerhin yeterli bir güvence olduğu yönünde Belgesay, Mustafa Reşit, Türk Kanunu Medenisi Şerhi, Üçüncü Kitap, Miras, 4. Baskı, İstanbul 1952, s. 58.

28 Mevcut kanunî düzenlemenin yorumundan, şerhin tek başına yeterli olmaması halinde önmirasçıdan ek güvence talebinde bulunulabileceği sonucuna varan, kanımızca da isabetli görüş olarak bkz. Gürpınar, s. 190; Aksi görüşte şerh verildiği durumda artmirasçının başkaca güvence isteyemeyeceğine ilişkin bkz. Gönensay/Birsen, s. 151; İnan/Ertaş/Albaş, N. 716. 


\section{B. Artvasiyet Alacaklısı Atama Tasarrufu Bakımından}

Türk Medenî Kanunu m. 521/III uyarınca artmirasçı atamaya ilişkin hükümler belirli mal bırakma tasarrufunda da uygulanma alanı bulmaktadır. Yani mirasbırakanın bu yolla belirli mal birakma tasarrufunda bulunması da mümkündür ${ }^{29}$. Bu durumda artık önmirasçı ile artmirasçıdan değil, önvasiyet alacaklısı ile artvasiyet alacaklısından söz etmek gerekir. Ancak söz konusu uygulamanın kurumun bünyesine uygun düştüğü ölçüde olacağı da belirtilmelidir. Zira artvasiyet alacaklısı artmirasçıdan farklı olarak cüz'î haleftir ${ }^{30}$.

Artvasiyet alacaklısı atamada terekenin defterinin tutulmasına gerek yoktur. Ancak vasiyetin konusunu oluşturan şeylerin çok fazla olması halinde defter tutulmasında yarar görülmektedir ${ }^{31}$. Artvasiyet alacaklısı atamada da kazandırmanın önvasiyet alacaklısına teslimi için güvence gösterme zorunluluğu bulunur ${ }^{32}$. Bu kapsamda taşınmazı artvasiyet alacaklısına geçirme yükümlülüğünün tapu kütüğüne şerh verilmesi mümkündür ${ }^{33}$.

\section{Miras Kapsamında Yer Alan Taşınmazın Mülkiyetinin Artmirasçıya/Artvasiyet Alacaklısına Geçmesinin Hukukî Niteliği}

Artmirasçı atamada önmirasçının mirasçılığının sona erdiği an, artmirasçı mirasçı sıfatını kazanır. Geçiş anının vade olarak belirli bir zaman şeklinde belirlenmesi mümkün olduğu gibi, koşula bağlanması da mümkündür ${ }^{34}$. Mirasbırakanın mirasın artmirasçıya geçeceği anı belirlemediği durumda ise TMK m. 522/I uyarınca miras önmirasçının ölümü ile artmirasçıya geçer. Yine mirasbırakan tarafından belirlenen geçiş anının gelmesinden önce önmirasçının ölmesi de mümkündür. Bu durumda miras doğrudan artmirasçıya geçmemekte, önmirasçının mirasçılarına teslim edilmekte (TMK m. 522/II) ve geçiş anının gelmesi ile birlikte artmirasçıya devir yükümlüğü artık önmirasçının mirasçılarının olmaktadır ${ }^{35}$. Buna karşılık önmirasçı mirasbırakanın ölümü anında sağ değilse, mirastan yoksunsa ya da mirası reddetmişse miras doğrudan artmirasçıya geçer (TMK m. 525/III). Ancak bunun için yedek mirasçının da bulunmaması gerekir ${ }^{36}$.

29 Tuor, $\S 71$, N. 24; İmre/Erman, s. 150; Dural/Öz, N. 831; İnan/Ertaş/Albaş, N. 703; Antalya/Sağlam, s. 202; Weimar, Art. 488, N. 16; Eren/Yücer Aktürk, s. 156.

30 Köprülü, s. 197; İnan/Ertaş/Albaş, N. 711; Hrubesch-Millauer, Art. 491, N. 4; Ayan, s. 139-140; Yarg. 3. HD, 17.9.2013, E. 2013/9040, K. 2013/12823; Yarg. 3. HD, 02.04.2018, E. 2018/1129, K. 2018/3329 (https://emsal.yargitay. gov.tr, 1.04.2019).

31 Dural/Öz, N. 816; İnan/Ertaş/Albaş, N. 715; Hrubesch-Millauer, Art. 490, N. 6; Studhalter, Art. 490, N. 2; Weimar, Art. 490, N. 7.

32 Escher/Escher, Art. 490, N. 7, Vorbem. Art. 488-493, N. 9; Gürsoy, s. 178-179; Hrubesch-Millauer, Art. 490, N. 11; Ayan, s. 140.

33 Gürsoy, s. 179; Doğan, s. 186; Aybay/Hatemi, (Hatemi), § 11, N. 91; Çabri, N. 699.

34 Dural/Öz, N. 823; Antalya/Sağlam, s. 202-203; Kılıçoğlu, s. 153; Studhalter, Art. 488, N. 1; Weimar, Vorbem. zu Art. 488, N. 15.

35 Escher/Escher, Art. 490, N. 8; Oğuzman, s. 155; Kocayusufpaşaoğlu, s. 294; Hrubesch-Millauer, Art. 489 , N. 1.

36 Escher/Escher, Art. 492, N. 13; İmre/Erman, s. 163; Dural/Öz, N. 823; Hrubesch-Millauer, Art. 492, N. 4-5; Aynı şekilde TMK m. 521/III dolayısıyla önvasiyet alacaklısı mirasbırakanın ölümü anında sağ değil ise, mirastan yoksun 
Öğretide mirasın geçiş anı geldiğinde miras kapsamında yer alan eşyaların-çalışma özelinde taşınmazların-mülkiyetinin artmirasçıya geçişinin kendiliğinden mi olacağı, yoksa burada önmirasçıya veya onun mirasçılarına karşı ileri sürülebilecek bir alacak hakkının mı söz konusu olduğu tartışmalıdır. Yine artvasiyet alacaklısının durumu da ayrıca ele alınmalıdır.

İlk görüşe göre ${ }^{37}$ miras artmirasçıya TMK m. 522 uyarınca mirasbırakan tarafından belirlenebilecek geçiş anının gelmesi ile birlikte geçmektedir. Artmirasçı atamada, önmirasçının miras hakkı vade veya bozucu koşula bağlı iken, artmirasçının miras hakkı vade veya geciktirici koşula bağlıdır. Artmirasçının beklenen bir hakkı vardır (TMK m. 523/III). Geçiş anı olarak kabul edilen vadenin gelmesi ya da koşulun gerçekleşmesiyle, mirasın geçişi kendiliğinden kanun gereği olur (TMK m. 599). Dolayısıyla artmirasçının mirası kazanması için herhangi bir işleme gerek yoktur.

Söz konusu görüş taşınmazlar özelinde değerlendirilirse, geçiş anı gelerek artmirasçının mirası kazanması ile tapuda önmirasçı adına yapılmış tescil yolsuz hale gelecektir ${ }^{38}$. Yani artmirasçıya geçiş aynî etkilidir. Bu nedenle vadenin gelmesi ya da koşulun gerçekleşmesi veya mirasbırakanın ölümü anında önmirasçının sağ olmamasıyla artmirasçı mirası kazanırsa (TMK m. 525/III), onun artık aynî bir talep hakkı olur. Mirasçıların mirasbırakanın ölümüyle mirası bir bütün olarak kanun gereğince kazandıklarını düzenleyen TMK m. 599 hükmü artmirasçının mirası kazanması bakımından da uygulanmalıdır. Böylece nasıl ki TMK m. 599 uyarınca önmirasçının ve diğer mirasçıların mirası kazanması küllî halefiyet yolu ile gerçekleşiyorsa, artmirasçının mirası kazanması da küllî halefiyetle gerçekleşir ${ }^{39}$. Dolayısıyla artmirasçı istihkak talebi ile taşınmazın adına tescil edilmesini isteyebilir. Taşınmazın artmirasçıya devrinin rıza ile yapılmaması halinde, artmirasçının yapması gereken, önmirasçı veya onun mirasçılarına karşı TMK m. 637’ye dayalı miras sebebiyle istihkak davası ${ }^{40}$ açmaktır.

Artvasiyet alacaklısı atamada ise taşınmazın mülkiyetinin geçişi kendiliğinden olmamakta, vasiyet alacağından söz edilmektedir. Türk Medenî Kanunu m. 521/III’te artvasiyet alacaklısı bakımından artmirasçı atamaya ilişkin hükümlerin uygulanacağı belirtildiğinden, geçiş anının gelmesi ile birlikte artvasiyet alacaklısının vasiyet alacağını kazandığı sonucuna varılmalıdır. Eş söylemle lehine belirli mal bırakılan artvasiyet alacaklısı, ölüme bağlı tasarrufta aksi belirtilmemişse geçiş

kalmışsa ya da mirası reddetmişse, vasiyetin artvasiyet alacaklısına geçeceğine ilişkin Hrubesch-Millauer, Art. 492, N. 7; Çabri, N. 732-N. 734.

37 Escher/Escher, Art. 491, N. 3, Art. 492, N. 2, N, 5, N. 7; Belgesay, s. 56; Ayiter, Nuşin, Miras Hukuku, 4. Bası, Ankara 1978, s. 86; Kocayusufpaşaoğlu, s. 292; Köprülü, s. 196; Sirmen, Lâle, Türk Özel Hukukunda Şart, Ankara 1992, s. 106; İmre/Erman, s. 162; Dural/Öz, N. 825, N. 827; Hrubesch-Millauer, Art. 492, N. 1; Ayan, s. 139; Nomer, Halûk N., Beklenen Haklar Üzerindeki Tasarrufların Hukukî Sonuçları, İstanbul 2002, s. 137; Honsell/ Vogt/Geiser, Art. 491, N. 1-2; Öztan, Bilge, Miras Hukuku, 9. Baskı, Ankara 2018, s. 311; Kılıçoğlu, s. 153; Weimar, Art. 489, N. 3, Art. 492, N. 3, Vorbem. zu. Art. 488, N. 15; Çabri, N. 684-685, N. 715; Eren/Yücer Aktürk, s. 160.

38 Escher/Escher, Art. 492, N. 7.

39 Escher/Escher, Art. 492, N. 2, N. 5; İmre, s. 200-201; Dural/Öz, N. 830; Hrubesch-Millauer, Art. 492, N. 1; Ayan, s. 139.

40 Akbıyık, Cem, Miras Sebebiyle İstihkak Davası, İstanbul 2003, s. 176. 
anının gelmesi ile önvasiyet alacaklısına karşı alacak hakkı sahibi olur (TMK m. 600) ${ }^{41}$. Vasiyetin yerine getirilmemesi halinde artvasiyet alacaklısı ifayı sağlamak için dava yoluna başvurmalıdır ${ }^{42}$.

Şu halde bu görüşe göre vasiyete konu şey bir taşınmaz ise, geçiş anında taşınmazın mülkiyetinin kendiliğinden artvasiyet alacaklısına geçmediği sonucuna varılır. Geçiş anının gelmesi ile önvasiyet alacaklısının taşınmazı devir borcu muaccel olmakta ve artvasiyet alacaklısı taşınmazın mülkiyetinin kendisine devrini isteme konusunda alacak hakkı elde etmektedir. Önvasiyet alacaklısı taşınmazın mülkiyetini artvasiyet alacaklısına devretmez ise, geçiş anının mirasbırakan tarafından açıkça belirlendiği durumda - diğer bir ifade ile vadenin bulunması halinde - ihtara gerek olmaksızın, vadenin bulunmadığı geçişin koşula bağlı olduğu durumda ise artvasiyet alacaklısının ihtarı ile $\left(\mathrm{TBK}^{43} \mathrm{~m}\right.$. 117) önvasiyet alacaklısı temerrüde düşer. Bunun üzerine artvasiyet alacaklısı TMK m. 716 uyarınca dava açarak mahkemeden taşınmazın mülkiyetinin kendisine devredilmesini ve bununla beraber borcun zamanında ifa edilmemesi sebebi ile uğramış olduğu zararların tazminini (TBK m. 118; gecikme tazminatı) isteyebilecektir. Böylece mahkeme kararı ile artvasiyet alacaklısı vasiyet konusu şeyin mülkiyetini kazanmış olur ${ }^{44}$.

İkinci görüşe göre ${ }^{45}$, geçiş anının gelmesi ile artmirasçı kendiliğinden mülkiyet hakkını kazanamaz. Burada bir tescilsiz kazanma hali yoktur. Bu görüş uyarınca bir kişi yalnızca kendisi için mirasçı atayabilir. Mirasbırakanın bir kimseyi mirasçı atadıktan sonra, örneğin bu kişinin ölümü ile terekesinin başka bir kişiye geçeceğini belirtmesi, mirasçı atama anlamına gelmez. Artmirasçı atamada yalnızca önmirasçı küllî halef, artmirasçı önmirasçıya veya onun mirasçılarına karşı ileri sürülebilecek bir alacak hakkı sahibidir. Eş söylemle artmirasçı atamada yalnızca önmirasçı atanmış mirasçı olmakta, artmirasçı yalnızca vasiyet alacaklısı olabilmektedir. Artmirasçı ya da artvasiyet alacaklısı atamada farklı sonuçların benimsenmesine gerek yoktur. Gerek artmirasçı gerekse artvasiyet alacaklısı geçiş anının gelmesi ile alacak hakkı sahibi olur. Nitekim tapu sicil sisteminde bozucu koşula bağlı tescil talebi mümkün değildir.

Üçüncü görüş ${ }^{46}$ ise koşula bağlı mülkiyet hakkının İsviçre/Türk Hukuk’larına yabancı olduğunu belirtmektedir. Koşula bağlı bir hakkın tapu siciline tescil edilmesi mümkün değildir. Bu görüşe göre önmirasçı koşula bağlı bir hakkın değil, mülkiyet hakkının sahibidir. Ancak aynı zamanda mirasın önmirasçıdan artmirasçıya geçirilmesi yükümlülüğü söz konusudur. Geçiş anı geldiğinde mallar - çalışma özelinde taşınmazlar - kendiliğinden artmirasçıya geçer. Ancak

41 Dural/Öz, N. 831; Hrubesch-Millauer, Art. 488, N. 21, Art. 491, N. 4; Ayan, s. 139-140; Antalya/Sağlam, s. 202 , s. 204 dn. 740; Kılıçoğlu, s. 150 dn. 139.

42 Çabri, N. 734.

43 Türk Borçlar Kanunu, Kanun No: 6098, Kabul Tarihi: 11.01.2011, Resmî Gazete Tarihi: 04.02.2011, Sayı: 27836, Yürürlük Tarihi: 01.07.2012.

44 Çabri, N. 721; Burada TMK m. 716’ya dayanılmasının sebebi davanın temelinde aynî hak değişikliği yaratacak bir kişisel hakkın bulunmasıdır, Özmen, Etem Sabâ/Aydın, Güilșah Sinem, "Tapu İptal Davası Olarak Yanlış Adlandırma ile Açılan Davalar (Tescili İsteme Davası/Yolsuz Tescilin Düzeltilmesi Davası)”, İstanbul Barosu Dergisi, C. 88 , S. 2014/6, (s. 179-215) s. 198. Aybay/Hatemi (Hatemi), $\$ 11$, N. 92-93, $\$ 24$, N. 4; Vardar Hamamc1oğlu, s. 197. 
geçişin kendiliğinden olması, bu kurumun koşul kavramı ile açıklanmasını zorunlu kılmaz, burada mükellefiyetin olduğu kabul edilmelidir.

Kanımızca ilk görüş ile aynı yönde olarak, artmirasçı atamada önmirasçının mirasçı sıfatının vade veya bozucu koşula bağlı iken, artmirasçının sıfatının vade veya geciktirici koşula bağlı olduğu kabul edilmelidir ${ }^{47}$. Miras kapsamında yer alan taşınmazların mülkiyetinin artmirasçıya geçişi ise, geçiş anının gelmesi ile birlikte kendiliğinden ve kanun gereği olur. Tıpkı TMK m. 599 uyarınca mirasçının mirası bir bütün olarak kanun gereği kazanmasında olduğu gibi ${ }^{48}$, artmirasçının mirası kazanması da küllî halefiyete dayanan bir tescilsiz kazanma halidir ${ }^{49}$. Dolayısıyla geçiş anının gelmesi ile miras kapsamında yer alan taşınmaz bakımından tapuya yapılmış tescil yolsuz hale gelir. Sonrasında artmirasçı adına yapılacak olan tescil açıklayıcı (bildirici) tescil olmaktadır. Önmirasçının devir yükümlülüğünü kendi rızası ile gerçekleştirmemesi halinde artmirasçı, önmirasçı veya onun mirasçılarına karşı ister TMK m. 637 uyarınca miras sebebi ile istihkak davası isterse TMK m. 1025’e dayalı tapu sicilinin düzeltilmesi davası açabilir. Önmirasçının taşınmaza malik olması bakımından artmirasçı atama, taşınmazlar üzerinde yapılan tasarruf işlemlerinin bozucu koşula bağlanamayacağına ilişkin kuralın (TBK m. 243 ve TST m. 16/II) bir istisnasını oluşturur ${ }^{50}$. Artvasiyet alacaklısı ise artmirasçıdan farklı olarak cüz'î haleftir. Artvasiyet alacaklısı geçiş anında vasiyet konusu şey üzerinde doğrudan hak sahibi olmamakta, yalnızca vasiyet konusunun kendisine devri konusunda alacak hakkı sahibi olmaktadır ${ }^{51}$.

\section{III. Önmirasçının/Önvasiyet Alacaklısının Miras Kapsamında Yer Alan Taşınmaz Üzerindeki Tasarruf Yetkisinin Kısıtlı Olup Olmadığı Hususu}

Önmirasçı, mirasın artmirasçıya geçişi anına kadar kendisine intikal eden taşınmazlar üzerinde mülkiyet hakkına sahip olduğundan, bu hakkı dolayısıyla sahip olduğu tasarruf yetkisine dayanarak fiilî ya da hukukî tasarruflarda bulunabilir. Böylece önmirasçı, taşınmazların terekeden çıkmasına (örneğin başkasına mülkiyeti devir yolu ile) ya da artmirasçının mülkiyet hakkının sınırlanmasına (örneğin başkası lehine sınırlı aynî hak tanınması veya kişisel hakların şerh verilmesi yolu ile) neden olabilir ${ }^{52}$. Ancak önmirasçının terekeyi yönetme konusunda hak sahibi ve yükümlü olduğu da unutulmamalıdır. Zira önmirasçının sahip olduğu mülkiyet hakkı ona eşyalar üzerinde yönetme yetkisi de vermektedir. Yönetme yetkisi kapsamında tasarruf yetkisi de yer alır ${ }^{53}$. Yapılan tasarruf, yönetme yetkisinin kullanılması bakımından zorunlu ise tasarrufun

47 Önmirasçının mirasçılığının bozucu koşula, artmirasçının mirasçılığının ise geciktirici koşula bağlı olduğu, ancak artmirasçı atamanın koşula bağlı bir işlem olmadığı, bünyesinde koşul içeren bir işlem olduğuna ilişkin görüş olarak ayrıca bkz. Kılıçoğlu, s. 153.

48 Hrubesch-Millauer, Art. 492, N. 1.

49 Aynı yönde İmre, s. 200-201.

50 Aynı yönde Sirmen, s. 106; Yakuppur, Sendi, Tapu Kütüğüne Güven İlkesi, İstanbul 2016, s. 88 dn. 302.

51 Aynı yönde Oğuzman, s. 156; Dural/Öz, N. 831; Ayan, s. 139-140; Hrubesch-Millauer, Art. 488, N. 4, N. 21, Art. 491, N. 4; Studhalter, Art. 488, N. 13; Yarg. 3. HD., 17.9.2013, E. 2013/9040, K. 2013/12823; Yarg. 3. HD, 02.04.2018, E. 2018/1129, K. 2018/3329 (https://emsal.yargitay.gov.tr, (1.04.2019).

52 Escher/Escher, Art. 491, N. 14; Gürpınar, s. 140.

53 Escher/Escher, Art. 491, N. 11; Ayiter, s. 85; Tuor, $\$ 71$, N. 28; Studhalter, Art. 491, N. 8; Gürpınar, s. 131. 
geçerliliği kesindir ${ }^{54}$. Bu durumda tasarruf edilen eşyanın yerine terekeye giren bir kaim değer varsa, geçiş anı geldiğinde onun artmirasçıya devri gerekir ${ }^{55}$.

Önmirasçı yönetme yetkisinin bir gereği olmaksızın, artmirasçıya devretmekle yükümlü olduğu eşyalar üzerinde, artmirasçının haklarını tehlikeye düşürecek şekilde tasarrufta bulunmamalıdır. Ama artmirasçıya mirasın geçtiği ana kadar önmirasçı intikale konu eşyalar üzerinde mülkiyet hakkına sahip olduğundan, bu tür tasarruflarda bulunması bir olasılıktır. Bu kapsamda önmirasçının yönetme hak ve yükümlülüğü kapsamına girmeyen bir tasarrufta bulunması bakımından, tasarruf yetkisinin kısıtlı olup olmadığ öğretide tartışılmaktadır ${ }^{56}$.Zira önmirasçının mirasçı sıfatı devam ederken, artmirasçının haklarını tehlikeye düşürecek - yani onun hakkına kavuşmasını engelleyecek ya da hakkını sınırlayacak - tasarruflarda bulunması halinde, bu tasarrufların geçerli olup olmayacağına ilişkin açık bir kanunî düzenleme bulunmamaktadır. Söz konusu tartışma kapsamında ileri sürülen görüşler temelde iki grupta toparlanabilir. Çalışma taşınmazlar ile sınırlı olduğundan, görüşler özellikle taşınmazlar bakımından ele alınacak, her bir görüş açısından artmirasçı atanmasına ilişkin şerhin etkisi tespit edilecek ve devamında kanaatimiz ortaya konacaktır.

\section{A. Önmirasçının Tasarruf Yetkisi Bakımından Öğretide İleri Sürülen Görüşler}

\section{I. Önmirasçının Tasarruf Yetkisinin Kısıtlı Olduğu Görüşü}

Öğretide hâkim olan görüşe göre önmirasçı miras kapsamında yer alan eşyalarda - çalışma özelinde taşınmazlarda - mülkiyet hakkına sahip olsa da, tasarruf yetkisi hukuken kısıtlanmıştır. Önmirasçının mülkiyet hakkı artmirasçıya geçiş anı geldiğinde sona erer. Geçiş anından önce önmirasçı tarafından yapılan ve artmirasçının haklarını ihlâl eden tasarruflar ise geçiş anının gelmesi ile birlikte ihlâl ettiği oranda artmirasçıya karşı geçersiz olur ${ }^{57}$. Bu durumda artmirasçı taşınmazlar bakımından söz konusu tasarrufların tapu sicilinden silinmesini isteyebilir ${ }^{58}$. Zira TBK m. 171/II uyarınca koşulun gerçekleşmesinden önce yapılan tasarruflar, koşulun

54 Tuor, $\S 71$, N. 28; Hrubesch-Millauer, Art. 491, N. 9; Örnek olarak önmirasçının, komşu arazinin çöp toplama merkezi haline getirilecek olması nedeni ile taşınmazın değerinin düşeceğini anlayıp taşınmazı elden çıkarması verilebilir, Gürpınar, s. 137; “... Alelade mirasçı gibi malları iktisap edecek olan davacının, veraset ve intikal vergisi vereceği muhakkak bulunduğuna göre bunu ödemek için veya malların idaresini kolayca yürütülebilmek için, kendisine intikal eden mallar üzerinde temliki tasarrufta bulunması doğaldır. ..., Yarg. HGK, 10.11.1982, E. 1981/2-77, K. 1982/881, legalbank.net (1.04.2019).

55 Tuor, $\$ 71$, N. 25; İmre/Erman, s. 157; Hrubesch-Millauer, Art. 491, N. 11; Antalya/Sağlam, s. 204; Weimar, Art. 491, N. 7.

56 Bkz. Başlık III., A., 1. ve 2.

57 Escher/Escher, Art. 491, N. 3, N. 11; Belgesay, s. 59; Saymen, s. 138; Gönensay/Birsen, s. 152; Ayiter, s. 84-85; Tuor, $\$ 71$, N. 28; İmre/Erman, s. 157; Dural/Öz, N. 810; Nomer, s. 138; Serozan/Engin, $₫ 4$, N. 177; Doğan, s. 185; Öztan, s. 309; Antalya/Sağlam, s. 203; Hrubesch-Millauer, Art. 491, N. 9; Studhalter, Art. 491, N. 8; Yakuppur, s. 91.

58 Escher/Escher, Art. 490, N. 8; Ayiter, s. 85; Antalya/Sağlam, s. 203; Artmirasçının bu tasarrufların iptalini isteyebileceği yönünde İmre, s. 207; İmre/Erman, s. 157; Öztan, s. 309. 
hükümlerini zedelediği oranda geçersiz olmaktadır. Bu hüküm artmirasçının haklarını ihlâl eden tasarruflar bakımından da kıyasen uygulanmalıdır ${ }^{59}$.

Bu görüş uyarınca artmirasçı atanmasına ilişkin şerhe (TMK m. 1010/I, b. 3) bağlı olmaksızın, önmirasçının tasarruf yetkisi hukuken kısıtlı kabul edildiğinden, şerhin etkisi kurucu değil açıklayıcıdır ${ }^{60}$. Şerh tapu kütüğünü kilitlememekte, önmirasçının tapuda tasarrufta bulunmasını engellememektedir ${ }^{61}$. Şerhin etkisi iyiniyeti ortadan kaldırıcı niteliktedir. Şerh, TMK m. 1023 uyarınca önmirasçıdan miras kapsamında yer alan taşınmaz üzerinde aynî hak kazanan üçüncü kişinin iyiniyetini ortadan kaldırır. Bu görüşe göre tapu sayfasında şerh yoksa ve artmirasçı

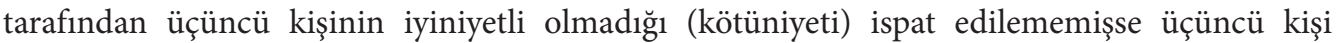
iyiniyetli sayılır (TMK m. 3) ve TMK m. 1023 uyarınca üçüncü kişinin kazanımı korunur ${ }^{62}$. Bu durumda artmirasçı zararının tazminini önmirasçıdan, önmirasçı ölmüşse onun mirasçlarından isteyecektir ${ }^{63}$. Ama tapu sayfasında şerh bulunmamakla beraber önmirasçıdan taşınmazı kazanan kimse iyiniyetli değilse TMK m. 1023 uyarınca kazanımı korunmayacak ve geçiş anının gelmesi ile beraber taşınmazın mülkiyeti artmirasçıya geçecektir ${ }^{64}$. Buna karşılık öğretide bir görüşe göre artmirasçı atanmasına ilişkin şerh tasarruf yetkisi kısıtlamasını açı hale getirir. Ancak şerhin bulunmadığı dönemde önmirasçı ile tasarruf işlemi yapan üçüncü kişilerin iyiniyetli olsalar dahi taşınmazda aynî hak kazanmaları mümkün değildir. Türk Medenî Kanunu m. 1023 uyarınca kazanımı korunabilecek olanlar, önmirasçıdan taşınmazda aynî hak kazanan kimseden, yine aynı taşınmaza ilişkin aynî hak kazanan iyiniyetli üçüncü kişilerdir ${ }^{65}$.

\section{2. Önmirasçının Tasarruf Yetkisinin Hukuken Kısıtlı Olmadığı Görüşü}

Öğretide azınlıkta kalan görüşe göre, önmirasçının miras kapsamında yer alan eşyalar üzerindeki tasarruf yetkisi hukuken kısıtlı değildir ${ }^{66}$. Önmirasçının bu eşyalar üzerindeki hakkının bozucu

59 Saymen, s. 138; Ayiter, s. 84; İmre/Erman, s. 157; Nomer, s. 137-138; Yakuppur, s. 92; ZGB Art. 491/II'nin (TMK m. 524/II), OR Art. 151 vd. (TBK m. 170 vd.) ile tamamlanması gerektiği yönünde bkz. Hrubesch-Millauer, Art. 491, N. 5; Studhalter, Art. 491, N. 8; Güvenceye ilişkin hükmün, koşulun askıda olduğu duruma ilişkin hüküm olan OR Art. 152 (TBK m. 171) ile tamamlanması gerektiğine ilişkin Escher/Escher, Art. 490, N. 5; Ancak artmirasçının izin ya da onayı bulunuyorsa yapılan işlem bozucu koşula bağlı olmaksızın geçerli olacaktır, İmre, s. 207; Saymen, s. 138; İmre/Erman, s. 157; Hrubesch-Millauer, Art. 491, N. 9.

60 Nomer, s. 139; Doğan, s. 184; Yakuppur, s. 90.

61 Ayiter, s. 84-85; Nomer, s. 139; Antalya/Sağlam, s. 203; Yakuppur, s. 91.

62 Escher/Escher, Art. 490, N. 8, Art. 491, N. 13; İmre/Erman, s. 157 dn. 17; Dural/Öz, N. 810; Hrubesch-Millauer, Art. 491, N. 9; Nomer, s. 138-139; Studhalter, Art. 491, N. 9; Yakuppur, s. 90-91; İģüzzar/Demir/Yılmaz, s. 72.

63 İyiniyetli üçüncü kişilerin kazanımlarının korunması sebebi ile artmirasçının miras kapsamında yer alan değerleri elde edememesi durumunda, önmirasçının artmirasçıya haksız fiil hükümlerine göre tazminat ödemesi gerektiği yönünde Saymen, s. 139; İntifa hakkına ilişkin hükümler kapsamında önmirasçının TMK m. 800 uyarınca tazminat ödemesi hakkında bkz. Gönensay/Birsen, s. 152.

64 Gönensay/Birsen, s. 152; Hrubesch-Millauer, Art. 491, N. 9; Nomer, s. 139-140; Studhalter, Art. 491, N. 9.

65 Doğan, s. 139.

66 Çabri, N. 699 dn. 1221; “... Medeni Kanunda ön miraş̧ı durumunda olan davacının tasarruf yetkisini sinırlayan bir hüküm bulunmamaktadir...”, Yarg. HGK, 10.11.1982, E. 1981/2-77, K. 1982/881, legalbank.net (1.04.2019). 
koşula bağlı olduğu söylenemez ${ }^{67}$. Önmirasçı malik olarak tasarruf yetkisini dilediği gibi kullanmakta özgürdür. Önmirasçının tasarruf yetkisini kullanması neticesinde ondan aynî hak kazanan üçüncü kişilerin iyiniyetli olup olmadıklarının ise bir önemi yoktur. Üçüncü kişiler aynî hakkı kesin olarak kazanırlar. Önmirasçının yaptığı tasarruflar geçişle birlikte kendiliğinden hükümsüz hale gelmez. Zira önmirasçı mirasın artmirasçıya geçişi anına kadar miras üzerinde malik olarak dilediği gibi tasarruf etme hakkına sahiptir ${ }^{68}$. Her ne kadar TMK m. 5 uyarınca Türk Borçlar Kanunu’nun koşula ilişkin hükümlerinin kıyasen artmirasçı atamada uygulanması mümkünse de, bu kurumun niteliği gereği uygulanabilecek olan hüküm TBK m. 171/III değil, m. 173 hükmüdür. Böylece önmirasçının geçiş anından önce yaptığı tasarruf işlemlerinin geçiş anının gelmesi ile hükümden düşmeyeceği sonucuna varılır ${ }^{69}$.

Bu görüş uyarınca artmirasçı atanmasına ilişkin şerhin (TMK m. 1010/I, b. 3) etkisi şu şekilde açıklanabilir. Şerhten sonra da önmirasçının tasarruf yetkisi kısıtlanmaz. Dolayısıyla şerhten sonra tapu kütüğü kilitlenmemelidir. Şerhe rağmen önmirasçı taşınmaza ilişkin tasarruf işlemi yapabilir. Bu durumda önmirasçıdan miras kapsamında yer alan taşınmaz üzerinde aynî hak kazanan kişilerin durumunun bozucu koşul ile açıklanmasına gerek yoktur ${ }^{70}$. Zira başvurulması gereken hüküm TMK m. 1010/II'dir. Bu hüküm uyarınca şerhten sonra önmirasçının, artmirasçının haklarını ihlâl eden bir tasarrufta bulunması halinde, artmirasçıya karşı bu tasarruflar ileri sürülemez. Yani şerhe rağmen taşınmazda hak kazanan kişi, mirasın artmirasçıya geçişi anı geldiğinde hakkının o an itibarıyla sona ermesine, bu kapsamda hakkının dayandığı tescilin yolsuzlaşmasına TMK m. 1010/II uyarınca katlanmak zorundadır ${ }^{71}$. Şerhin bulunmadığı ve geçiş anı gelip mirasın artmirasçıya geçtiği durumda, önmirasçıdan taşınmazda aynî hak kazanan üçüncü kişilerin, artmirasçıya devir yükümlülügünü bilmediklerini yani iyiniyetli olduklarını ileri sürerek TMK m. 1023'e dayanmalarına gerek yoktur ${ }^{72}$. Bu kimseler hakkını tescil ile kazanmıştır. Mirasın artmirasçıya geçişi anı geldiğinde, söz konusu taşınmaz

67 Piotet, s. 110; Azınlık görüşüne sonucu itibarıyla katılmakla birlikte önmirasçının miras kapsamında yer alan değerler üzerindeki hakkının bozucu koşula bağlı olduğunu kabul eden görüş olarak bkz. Gürpınar, s. 151.

68 Piotet, s. 111; Gürpınar, s. 151; Çabri, N. 699 dn. 1221.

69 Gürpınar, s. 149-150.

70 Önmirasçının hakkının bozucu koşula bağlı olmasının, bu hak üzerindeki tasarrufların da kendiliğinden bozucu koşula bağlı olması sonucunu zorunlu olarak doğurmayacağına ilişkin Gürpınar, s. 148-149, s. 151-152.

71 Gürpınar, s. 148, s. 152; Şerhin önmirasçının taşınmaz üzerinde tasarruf yetkisini kısıtlamayacağı, ancak artmirasçının hakkını önmirasçıdan yeni hak kazananlara karşı koruyacağına ilişkin bkz. Gürsoy, s. 179; Verilen şerhin kural olarak önmirasçının tasarrufta bulunmasını engellemeyip, yalnızca artmirasçının hak sahibi olduğu anda hakkına kavuşmasını sağlamak amaçlı olduğu yönünde Özmen/Aydın, s. 199; Öğretide artmirasçı atanmasına ilişkin şerhin kurucu nitelikte olduğunu, yani şerhten önce tasarruf yetkisinin kısıtlanmış olmadığını kabul eden görüşün de azınlık görüşü ile uyumlu şekilde sonuca vardığı belirtilebilir. Şerhin kurucu nitelikte olduğu yönünde bkz. Oğuzman, M. Kemal/Seliçi, Özer/Oktay-Özdemir, Saibe, Eşya Hukuku, 21. Baskı, İstanbul 2018, N. 1055; Gümüiş, Mustafa Alper, Türk Medenî Kanununun Getirdiği Yeni Şerhler, İstanbul 2007, s. 16; Sirmen, Lâle, Eşya Hukuku, 6. Baskı, Ankara 2018 (Eşya), s. 217; Artmirasçı atanmasına ilişkin şerhin tapu kütüğünü kilitlemediği, ancak sonraki edinenlerin bu yükümlülüğün yerine getirilmesine katlanmak zorunda kaldığı yönünde Ertaş, Şeref, Eşya Hukuku, 13. Baskı, İzmir 2017, N. 815; Şerhten sonra önmirasçı üçüncü bir kişiye taşınmazda aynî hak sağlarsa, geçiş anı geldiğinde artmirasçının devralanlara karşı ileri sürebildiği bir alacak hakkına sahip olduğu görüşünde, Hatemi, $\$ 9$, N. 11; Vardar Hamamcioğlu, s. 197. 
artık terekede bulunmadığından, taşınmazın küllî halefiyet yolu ile tescilsiz kazanımı söz konusu olamaz $^{73}$. Bu durumda geçiş anının gelmesine rağmen devir yükümlülüğünü yerine getiremeyen önmirasçıdan, artmirasçı ancak tazminat isteyebilir. Ayrıca TMK m. 523 ile getirilen güvence gösterme yükümlülüğü de artmirasçının hakkını güvence altına almaktadır ${ }^{74}$.

\section{B. Görüşlerin Değerlendirilmesi ve Konuya Illişkin Kanaatimiz}

Türk Medenî Kanunu ve İsviçre Medenî Kanunu’nun artmirasçı atamaya ilişkin hükümleri incelendiğinde, mirasın artmirasçıya geçişi anına kadar önmirasçının tasarruf yetkisinin var olup olmadığına ilişkin açık bir hüküm bulunmamaktadır ${ }^{75}$. Bu nedenle kanımızca öğretide ileri sürülen görüşlerden hukukun ilkeleri ve Türk Borçlar Kanunu ile Türk Medenî Kanunu’nun bütünü göz önünde bulundurulduğunda hukuk sistemi ile en uyumlu olan görüşün benimsenmesi gerekir.

Önmirasçının tasarruf yetkisinin kısıtlı olduğunu kabul eden öğretideki hâkim görüş değerli hukukçular tarafından kabul edilmekteyse de, bu görüşün özellikle önmirasçıdan taşınmazlar üzerinde aynî hak kazanan üçüncü kişiler bakımından en âdil çözümü sunamadığı kanaatindeyiz. Şöyle ki; bu görüş uyarınca önmirasçıdan miras kapsamında yer alan taşınmaz üzerinde aynî hak kazanılması bozucu koşula bağlanmaktadır. Ancak bu sonuç eşya hukukunda geçerli olan tescilin koşula bağlanamayacağı genel kural1 ${ }^{76}$ ile çeliştiği için, eşya hukukuna hâkim prensiplerle uyum içinde olmaması yönüyle öğretide isabetli olarak eleştirilmektedir ${ }^{77}$. Gerçekten de TMK m. 1020/I’e göre "Tapu sicili herkese açıktır”. Ayrıca "Bir taşınmazın koşula bağh satışında, koşul gerçekleşmedikçe tapu siciline tescil yapılamaz" şeklindeki TBK m. 243/I hükmü ile koşulun tescille bağdaşmadığı vurgulanmıştır. Yine bu hususta TST m. 16/II'ye göre "İstem, tescili bozucu veya hükümsüz kılıcı kayıt ve şarta bağlanamaz”.

Gerçi öğretide hâkim görüşü savunan yazarlardan tapu sayfasında artmirasçı atanmasına ilişkin şerh (TMK m. 1010/I, b. 3) yoksa ve önmirasçıdan taşınmazı kazanan kimse iyiniyetli ise TMK m. 1023 uyarınca üçüncü kişinin kazanımının korunacağı da belirtilmektedir ${ }^{78}$. Ancak söz konusu tespit öğretide önmirasçının geçiş anına kadar taşınmazda malik olması sebebi ile TMK

73 Piotet, s. 110; Gürpınar, s. 148.

74 Piotet, s. 111; Gürpınar, s. 152.

75 Oysa Alman Medenî Kanunu’nun 2112. paragrafında, 2113-2115 numaralı paragraflardan aksi anlaşılmadı̆̆ı sürece, önmirasçının miras kapsamında yer alan şeyler üzerinde tasarruf edebileceği açıkça düzenlenmiştir.

76 Oğuzman/Seliçi/Oktay-Özdemir, N. 848; Esener, Turhan/Güven, Kudret, Eşya Hukuku, 7. Baskı, Ankara 2017, s. 141; Tekinay, Selâhattin Sulhi/Akman, Sermet/Burcuoğlu, Halûk/Altop, Atilla, Tekinay Eşya Hukuku, Cilt I, İstanbul 1989, s. 331; Sirmen, s. 104 vd.; Akipek, Jale/Akıntürk, Turgut/Ateş, Derya, Eşya Hukuku, İstanbul 2018, s. 296-297; Nomer, Halûk Nami/Ergüne, Serkan, Eşya Hukuku, 6. Bası, İstanbul 2019, N. 402.

77 Gürpınar, s. 145.

78 Saymen, s. 139-140; İmre/Erman, s. 157 dn. 17; Dural/Öz, N. 810; Nomer, s. 138-139; Bu durumda yolsuz bir tescil mevcut olmamakla birlikte tapudaki kaydın tam olarak gerçeği yansıtmaması nedeniyle işlem tarafı üçüncü kişilerin TMK m. 1023'deki korumadan faydalanabileceği yönünde Yakuppur, s. 91. 
m. 1023 hükmünün uygulanamayacağ gerekçesi ile eleştirilmektedir $^{79}$. Gerçekten de TMK m. 1023 hükmünün uygulanma koşullarından biri, iyiniyetli üçüncü kişinin güvendiği sicil kaydının yolsuz olmasıdır ${ }^{80}$. Oysa önmirasçı artmirasçıya geçiş anına kadarki süreçte taşınmazın maliki olduğundan, üçüncü kişinin aynî hak kazandığı sırada önmirasçı adına tapuda bulunan tescil yolsuz bir tescil değildir. Dolayısıyla bu durumda TMK m. 1023 hükmünün uygulanabileceği görüşüne biz de katılmamaktayız.

Kanaatimizce en ideal olan, önmirasçının miras kapsamında yer alan değerler üzerindeki tasarruf yetkisinin var olup olmadığının kanun koyucu tarafından düzenlenmesi ve öğretide ileri sürülen görüşlerden birinin kanunda açıkça benimsenmesidir. Biz bu hususta önmirasçının tasarruf yetkisinin kısıtlı olmadığını kabul eden azınlık görüşünün, vardığı sonuçları itibarıyla gerek hukukun ilkeleri gerekse Türk Borçlar Kanunu ve Türk Medenî Kanunu'nun sistemi ile daha uyumlu olduğu kanaatindeyiz ${ }^{81}$. Ancak azınlık görüşünden bir noktada ayrılarak önmirasçının eşyalar üzerindeki hakkının bozucu koşula bağlı olduğunu kabul eden öğretideki görüşe ${ }^{82}$ de katılmaktayız. Böylece önmirasçının miras kapsamında yer alan değerler - çalışma özelinde taşınmazlar - üzerindeki hakkı bozucu koşula bağlıdır. Bu yönü ile artmirasçı atama tasarrufu, taşınmazlar üzerinde yapılacak tasarruf işlemlerinin bozucu koşula bağlanamayacağına ilişkin kuralın bir istisnasını oluşturur. Ancak önmirasçının hakkının bozucu koşula bağlı olması, önmirasçının yaptığı tasarrufların da kendiliğinden bozucu koşula bağlı olmasına yol açmaz. Bozucu koşul ileriye etkili sonuç doğurur. Mirasın geçişi anından önce önmirasçının miras kapsamında yer alan taşınmazlar üzerindeki mülkiyet hakkı ve bu hak kapsamda tasarruf yetkisi tamdır ${ }^{83}$. Mirasın geçiş anı geldiğinde miras kapsamında yer alan taşınmaz hâlâ önmirasçının mülkiyetinde ise artık mülkiyet hakkı sona erer ve artmirasçı taşınmazı kanun gereği ve kendiliğinden kazanır. Bu bir tescilsiz kazanma hali olduğu için geçiş anının gelmesi ile birlikte tapuda önmirasçı adına bulunan tescil yolsuz hale gelir. Önmirasçının devir yükümlülügünü kendi rızası ile gerçekleştirmemesi halinde ise, artmirasçının yapması gereken önmirasçı veya onun mirasçılarına karşı TMK m. 637 uyarınca miras sebebi ile istihkak davasını ya da TMK m. 1025 uyarınca tapu sicilinin düzeltilmesi talepli adi istihkak davasını açmaktır. Buna karşılık geçiş anı geldiğinde taşınmaz önmirasçının mülkiyetinde değil ise söz konusu taşınmazın bozucu

79 Çabri, N. 699 dn. 1221.

80 Oğuzman/Seliçi/Oktay-Özdemir, N. 995; Ünal/Başpınar, s. 290-291; Ayan, Mehmet, Eşya Hukuku I, Zilyetlik ve Tapu Sicili, 13. Baskı, Ankara 2016 (Eşya), s. 230; Sirmen, Eşya, s. 199-200; Yakuppur, s. 44; Özçelik, Ş. Barış, Tapu Siciline Güvenin Korunması, Ankara 2016, s. 70; Aksi yönde yolsuz bir kayıt bulunmasa dahi, tapuda hak sahibi gözüken kişinin tasarruf yetkisine sahip olmadığı durumlarda üçüncü kişinin tapu kütügündeki kayda olan güveninin korunması gerektiğine ilişkin görüş olarak bkz. Nomer/ Ergüne, N. 435.

81 Aynı yönde karar olarak bkz. Yarg. HGK, 10.11.1982, E. 1981/2-77, K. 1982/881: “... Medeni Kanunda ön mirasçı durumunda olan davacının tasarruf yetkisini sinırlayan bir hüküm bulunmamaktadır. ..., legalbank.net (1.04.2019).

82 Gürpınar, s. 149.

83 Aynı yönde karar olarak bkz. Yarg. HGK, 10.11.1982, E. 1981/2-77, K. 1982/881: “... murisin ölümü üzerine taşınmazların ön mirasçı adına tapuya intikalen tescilinde kanuni sakınca yoktur. Zira, davacıya intikal eden miras intifa hakkından ibaret değildir. Davacı, mirası tüm mülkiyet hakları ile birlikte iktisap etmiş olduğu için ön mirasçının hakkının, olayda, intifa hakkıyla sınırlı olduğu iddia ve kabul edilemez. ...”, legalbank.net (1.04.2019). 
koşulun gerçekleşmesine dayalı olarak küllî halefiyet yolu ile artmirasçı tarafından kazanılması mümkün değildir. Mirasın artmirasçıya geçiş anı geldikten sonra, üçüncü kişilerin daha öncesinde önmirasçıdan kazandıkları haklar sona ermez ${ }^{84}$.

Ayrıca bu hususta TMK m. 171/III hükmünün kıyasen uygulanamayacağı kanaatindeyiz. Her ne kadar TMK m. 5 uyarınca Türk Borçlar Kanunu’nun genel nitelikli hükümlerinin tüm özel hukuk ilişkilerine uygulanabilmesi söz konusu ise de, kıyasen uygulama için uygulanacak hükmün kurumun niteliğine de uygun düşmesi gerekir. Oysa TBK m. 171/ III hükmünün, önmirasçının geçiş anından önce yaptı̆̆ uygulanması bu kurumun niteliğine uygun düşmez. Önmirasçının durumu inançlı işlemdeki inanılanın durumuna benzerdir ${ }^{85}$. Nasıl ki inanılan inançlı işleme konu olan taşınmazın tam anlamı ile maliki olduğundan onun yaptığı tasarruf işlemleri geçerli ise, önmirasçı da geçiş anına kadar taşınmazın maliki sıfatı ile geçerli şekilde tasarruf işlemleri yapabilir ${ }^{86}$.

Bu durumda artmirasçının aleyhine bir sonuç doğsa da, aslında kanunda çatışan menfaatler arasında bir denge mevcuttur. Şöyle ki; önmirasçı devir yükümlülügüüü tamamen ya da kısmen yerine getiremezse, artmirasçının zararını tazmin eder. Ayrıca artmirasçının, önmirasçının mirası teslim almasının bir koşulu olarak gösterdiği güvenceye başvurma imkânı da bulunmaktadır. Zaten güvence gösterme yükümlülügünün getirilmesinin amacı, önmirasçının mirası geçirme yükümlülüğünü yerine getirememesi halinde söz konusu zararın karşılanmasıdır ${ }^{87}$.

Şimdi katıldığımız görüş ışı̆̆ında, önmirasçının miras kapsamında yer alan taşınmazlar üzerindeki tasarruflarını, artmirasçı, artvasiyet alacaklısı ve bakiye üzerinde artmirasçı bakımından, mirasın geçiş anının öncesi ve sonrası ile tapuda TMK m. 1010/I, b. 3 uyarınca şerhin bulunup bulunmamasına göre ayrı ayrı ve detaylı olarak irdeleyeceğiz.

84 Aynı yönde Piotet, s. 110-111; Gürpınar, s. 148-149, s. 151-152.

85 Aynı yönde Gürpınar, s. 44; İnançlı ikame anlamına geldiği yönünde bkz. Saymen, s. 131; Önmirasçının durumunun inançlı bir işlem yapılan kimsenin durumuna da benzediğine ilişkin İmre, s. 207 dn. 25; Aksi yönde artmirasçı atamada önmirasçının durumunun intifa hakkı sahibinin durumuna benzediği, bu nedenle intifa hakkına ilişkin Türk Medenî Kanunu hükümlerinin artmirasçı atamanın bünyesi ve niteliğine uygun düştüğü ölçüde kıyas yolu ile uygulanabileceği şeklinde görüş olarak bkz. Oğuzman, s. 155; Kocayusufpaşaoğlu, s. 294; Hrubesch-Millauer, Art. 488, N. 3, Art. 491, 5-6; Antalya/Sağlam, s. 204; Studhalter, Art. 488, N. 3, Art. 491, N. 2, N. 4; Eren/Yücer Aktürk, s. 159; Önmirasçının hukukî durumunun intifa hakkı sahibinin hukukî durumuna benzediği yönünde bkz. Gönensay/Birsen, s. 153; Ayiter, s. 86; Tuor, \$71, N. 27; İşgüzar/Demir/Yılmaz, s. 71; Önmirasçının hakkının intifa hakkı ile sınırlı olduğunun kabul edilemeyeceğine ilişkin karar olarak bkz. Yarg. HGK., 10.11.1982, E. 1981/277, K. 1982/881, legalbank.net (1.04.2019).

86 Türk Medenî Kanunu m. 171/III hükmünün artmirasçı atama tasarruflarında kıyasen uygulamaya elverişli olmadığı ve önmirasçının geçiş anından önce yaptığı tasarruflar bakımından inançlı temlik işlemindeki inanılan gibi görülmesi gerektiğine ilişkin aynı yönde görüş olarak bkz. Gürpınar, s. 149, s. 152. 


\section{Artmirasçı Atama Tasarrufu Bakımından}

\section{a. Mirasın Artmirasçıya Geçişi Anından Önceki Aşama}

Önmirasçı bu aşamada miras kapsamında yer alan taşınmazı konu alan bir tasarruf işlemi yaparsa, işlemin geçerliliği bakımından, işlem anında tapuda artmirasçı atanmasına ilişkin şerhin bulunup bulunmamasına göre farklı sonuçlara varılır.

\section{aa. Tapuda Artmirasçı Atanmasına Ilişkin Şerhin Bulunmaması}

Tapuda artmirasçı atanmasına ilişkin şerh yoksa, bu aşamada önmirasçının yaptı̆̆ 1 tasarruf kesin olarak geçerlidir. Zira önmirasçı, mirasın artmirasçıya geçişi anına kadar, taşınmazda tam anlamı ile bir malikin hak ve yetkilerine sahiptir. Tasarruf yetkisi de mülkiyet hakkının malike sağladığı bir yetki olduğuna göre önmirasçının söz konusu taşınmaz üzerindeki tasarruf yetkisi de tamdır ${ }^{88}$. Tasarruf olarak önmirasçı miras kapsamında yer alan taşınmazın mülkiyetini üçüncü bir kişiye devredebileceği gibi, taşınmazda üçüncü kişi lehine sınırlı aynî hak kurabilir ya da taşınmazı konu alan kişisel hakkı tapuya şerh verebilir.

Önmirasçının taşınmazın mülkiyetini üçüncü kişiye devrettiği durumda, mirasın geçiş anının gelmesiyle, üçüncü kişi adına tapuda yapılan tescil yolsuz hale gelmez. Çünkü geçiş anında taşınmaz terekede yer almadığından, artmirasçı tarafından bu taşınmazın tescilsiz kazanımı mümkün değildir ${ }^{89}$. Yine önmirasçının üçüncü kişi lehine sınırlı aynî hak kurması ya da kişisel hakkı şerh etmesi halinde de, mirasın geçiş anı geldiğinde artmirasçı terekede mevcut olan taşınmazı sınırlı aynî hakla ya da kişisel hakkın şerhi ile yüklü olarak kazanır. Ancak bu durumda önmirasçı artmirasçıya tazminat ödemek durumunda kalır ${ }^{90}$. Şöyle ki; taşınmaza olması gerektiği şekilde kavuşamayan artmirasçı, olumlu zararının tazminini, TMK m. 5 hükmünde yapılan yollama gereğince TBK m. 112 hükmüne dayalı olarak önmirasçıdan isteyebilecektir. Zira önmirasçı kanundan doğan mirası artmirasçıya geçirme yükümlülüğünü (TMK m. 521/I) gereği gibi yerine getirememiştir ${ }^{91}$. Ayrıca artmirasçının, önmirasçının taşınmazı teslim almasının bir koşulu olarak gösterdiği güvencelere başvurma imkânı da bulunmaktadır.

\section{bb. Tapuda Artmirasçı Atanmasına Ilişkin Şerhin Bulunması}

Önmirasçının tasarruf işlemi yaptığı sırada tapuda artmirasçı atanmasına ilişkin şerh varsa, bir defa şerh olsa bile önmirasçının tasarruf yetkisi kısıtlanmaz. Bu nedenle tapu kütügünün işlemlere kapatılmaması gerekir. Çünkü şerh üzerine tapu kütügü işlemlere kapatılırsa TMK m. 1010/II’nin işlevi kalmaz. Dolayısıyla tapuda artmirasçı atanmasına ilişkin şerh bulunsa bile önmirasçı taşınmaz mülkiyetine ilişkin tasarruf işlemi yapabilmelidir. Şerhe rağmen taşınmazda

88 Aynı yönde Piotet, s. 111; Gürpınar, s. 151; Çabri, N. 699 dn. 1221.

89 Piotet, s. 110; Gürpınar, s. 148.

90 Aynı yönde Piotet, s. 111; Gürpınar, s. 152.

91 Artmirasçının zarar tazminini konu alan nisbî hakkı bakımından aynı yönde bkz. Özmen/Aydın, s. 199. 
aynî hak kazanan kişi ise, mirasın artmirasçıya geçişi anı geldiğinde hakkının o an itibarıyla sona ermesine katlanmak zorunda kalacaktır ${ }^{92}$ (TMK m. 1010/II). Bu durumda artmirasçı taşınmazın iadesini ya da taşınmazdaki mülkiyet hakkını sınırlayan ve şerhten sonra kurulan sınırlı aynî hakkın ya da kişisel hakkın şerhinin terkinini (TMK m. 1025) isteyebilecektir.

\section{b. Mirasın Artmirasçıya Geçişi Anından Sonraki Aşama}

Mirasın artmirasçıya geçiş anı geldiğinde artmirasçı, önmirasçının mülkiyetinde olan ve miras kapsamında yer alan taşınmazın mülkiyetine tescilsiz kazanma yoluyla kavuşur ve önmirasçı adına tapuda görünen tescil yolsuz hale gelir ${ }^{93}$. Devamında artmirasçı adına yapılacak olan tescil açıklayıcı tescildir. Bu aşamada önmirasçının yapması gereken, yükümlülügü uyarınca taşınmazı artmirasçıya kendi rızası ile devretmektir. Ancak önmirasçı bunu yapmayıp, artmirasçı hakkında açıklayıcı tescilin henüz yapılmadığı aşamada, taşınmazın hâlâ tapuda kendi adına tescilli olmasından yararlanarak, üçüncü bir kişiye aynı taşınmazda hak (mülkiyet hakkı, sınırlı aynî hak ya da kişisel hakkın şerhi)sağlayabilir. Bu durumda üçüncü kişinin aynî hak kazanımının korunup korunmayacağı tapuda artmirasçı atanmasına ilişkin şerhin bulunup bulunmamasına göre değişir. Ayrıca kişisel hakkın şerhinin korunup korunmayacağı hususu da ayrıca ele alınmalıdir.

\section{aa. Tapuda Artmirasçı Atanmasına ilişkin Şerhin Bulunmaması}

Tapuda artmirasçı atanmasına ilişkin şerh yoksa, üçüncü kişinin aynî hak kazanımı TMK m. 1023’ün koşullarının sağlanması şartı ile korunur. Çünkü bu aşamada artık geçiş anının gelmesi ile artmirasçı taşınmazın mülkiyetini tescilsiz olarak kazandığı için tapudaki önmirasçı adına gözüken tescil yolsuzlaşmıştır. Ancak TMK m. 1023 uyarınca tapudaki yolsuz tescile güvenerek aynî hak elde eden kimsenin kazanımının korunması için iyiniyetli olması da gereklidir.

Böylece üçüncü kişi TMK m. 3 anlamında iyiniyetli ise, yani devir anında artmirasçı atama tasarrufunun gereği olarak taşınmazın, geçiş anı geldiğinde artmirasçının mülkiyetine geçtiğini bilmiyorsa ya da bilecek durumda değilse aynî hakkı kazanır. Eğer kazanılan aynî hak mülkiyet hakkı ise artmirasçı taşınmazın mülkiyetini tamamen kaybederken; sınırlı aynî hak ise artmirasçı taşınmazın mülkiyetini söz konusu sınırlı aynî hakla yüklü olarak kazanır. Dolayısıyla mirasın geçiş anı geldiğinde her ne kadar artmirasçı tescilsiz kazanım ile taşınmazın maliki olmaktaysa da, bu aşamada iyiniyetli üçüncü kişiye aynî hak kazandırılması halinde söz konusu kazanımın TMK m. 1023 uyarınca korunması tehlikesi bulunduğundan, artmirasçı açıklayıcı tescilin yapılmasını geciktirmemelidir. Bu şekilde iyiniyetli üçüncü kişinin kazanımının korunması sonucunda miras kapsamında yer alan taşınmaza hiç ya da olması gerektiği şekilde kavuşamayan artmirasçı, olumlu zararının tazminini, TMK m. 5 hükmünde yapılan yollama gereğince TBK

92 Aynı yönde Çabri, N. 718.

93 Mirasın geçiş anı geldiğinde miras kapsamında yer alan taşınmazların mülkiyetinin artmirasçıya geçişinin kendiliğinden olacağını kabul eden görüş hakkında bilgi için bkz. Başlık II. 
m. 112 hükmüne dayalı olarak önmirasçıdan isteyebilir. Zira önmirasçı kanundan doğan mirası artmirasçıya geçirme yükümlülüğünü (TMK m. 521/I) gereği gibi yerine getirmemiştir.

Ayrıca mirasın geçiş anı gelmesine rağmen kendi rızası ile devri gerçekleştirmeyen önmirasçıya yöneltilmiş tapu sicilinin düzeltilmesi davası (TMK m. 1025) sürerken de taşınmazın önmirasçı tarafından üçüncü bir kişiye devredilmesi mümkündür. $\mathrm{Bu}$ durumda tapuda artmirasçı atanmasına ilişkin şerhin bulunmamasının yanı sıra, TMK m. 1011 uyarınca aynî hak iddiasının şerhi de yapılmamış ve iyiniyetli üçüncü kişinin TMK m. 1023 uyarınca kazanımı korunuyor ise, $\mathrm{HMK}^{94}$ m. 125/(1), a bendinin uygulanmasına yer olmadığı da vurgulanmalıdır. Şöyle ki; HMK m. 125/(1) davanın açılmasından sonra, davalının dava konusunu üçüncü bir kişiye devretmesi halinde davacıya iki tane seçimlik yetki vermektedir. Hükmün a bendi uyarınca davacı ister devreden tarafla olan davasından vazgeçerek dava konusunu devralmış olan kişiye karşı davaya devam eder, isterse b bendi uyarınca davasını devreden taraf hakkında tazminat davasına dönüştürür. Ancak HMK m. 125/(1), a hükmünün uygulanabilmesi için TMK m. 1023 uyarınca kazanım koşullarının gerçekleşmemiş olması gerekir ${ }^{95}$.

Buna karşılık üçüncü kişi TMK m. 3 anlamında iyiniyetli değil ise, yani devir anında artmirasçı atama tasarrufunun gereği olarak taşınmazın, geçiş anı geldiğinde artmirasçının mülkiyetine geçtiğini biliyorsa ya da bilmesi gerekiyorsa, bu kişinin aynî hak kazanımı TMK m. 1023 uyarınca korunmaz. Bu durumda artmirasçı üçüncü kişiye yönelteceği TMK m. 1025’e dayalı tapu sicilinin düzeltilmesi davası ile taşınmazın kendisine iadesini ister.

Ayrıca iyiniyetli olmayan üçüncü kişiye devir, artmirasçı tarafından önmirasçıya yöneltilmiş TMK m. 1025'e dayalı dava sürerken gerçekleştirilmişse, artık TMK m. 1023’e dayalı kazanım söz konusu olamayacağından, artmirasçının HMK m. 125/(1), a bendi uyarınca davasına üçüncü kişiye karşı devam edebileceği sonucuna varılır. Ancak TMK m. 3 uyarınca asıl olan iyiniyetin varlığıdır. Buna göre bir kimsenin iyiniyetli olmadığını iddia edenin bu iddiasını ispat etmesi gerekir. Buna ek olarak iyiniyetin ispatı, bu kavramın içsel (derunî) bir kavram olması sebebiyle kolay değildir. Bu nedenle tapuda artmirasçı atanmasına ilişkin şerh yoksa, kendi rızası ile devri gerçekleştirmeyen önmirasçıya yöneltilen TMK m. 1025 ’e dayalı davada, mutlaka TMK m. 1011/I, b. 1 uyarınca geçici tescil şerhi olarak aynî hak iddiasının tapuya şerhi istenmelidir. Böylece devamında dava konusu üçüncü kişiye devredilirse, şerhe rağmen devralan üçüncü kişinin iyiniyetli olmadığı kolaylıkla ispatlanacak ve HMK m. 125/(1), a bendi uyarınca davacı artmirasçı, davasına üçüncü kişiye karşı devam edebilecektir.

Bir diğer husus, artmirasçı tarafından önmirasçıya yöneltilen TMK m. 1025’e dayalı tapu sicilinin düzeltilmesi davası sürerken, önmirasçının dava konusu taşınmazı iyiniyetli olmayan üçüncü kişiye devrettiği ve artmirasçının HMK m. 125/(1), a bendi uyarınca davasına üçüncü kişiye

94 Hukuk Muhakemeleri Kanunu, Kanun No: 6100, Kabul Tarihi: 12.01.2011, Resmî Gazete Tarihi: 04.02.2011, Sayı: 27836, Yürürlük Tarihi: 01.10.2011.

95 Dava konusunu iktisap eden kişi iyiniyetli ise, iktisabı geçerli olduğundan ona karşı dava açılamaması gerektiği yönünde Börü, Levent, Dava Konusunun Devri, Ankara 2012, s. 332. 
karşı devam ettiği ihtimalde, üçüncü kişinin kazandırıcı zamanaşımına dayalı olarak mülkiyeti kazandığg şeklindeki savunmasının kabul edilip edilemeyeceğidir.

İlk olarak adına yolsuz tescil bulunan üçüncü kişinin bu davada TMK m. 712 uyarınca on yıllık olağan kazandırıcı zamanaşımı süresinin geçtiği gerekçesi ile taşınmazın mülkiyetini ya da irtifak hakkını (TMK m. 780/III'de yapılan yollama uyarınca) veya taşınmaz yükünü (TMK m. 840/III'de yapılan yollama uyarınca) kazandığını ${ }^{96}$ ileri sürmesi mümkün değildir. Zira olağan kazandırıcı zamanaşımı ile kazanımın koşullarından biri adına yolsuz tescil bulunan kişinin TMK m. 3 anlamında iyiniyetli olması, yani kendisinden beklenen tüm özeni göstermiş olmasına rağmen tescilin yolsuz olduğunu bilmemesidir ${ }^{97}$. Ancak artmirasçı atama tasarrufu bakımından şu anda incelediğimiz ihtimalde önmirasçıdan taşınmazda mülkiyet hakkı, irtifak hakkı ya da taşınmaz yükü elde eden üçüncü kişinin iyiniyetli olmadığı düşünüldüğünde, TMK m. 712'ye dayanması da mümkün olmaz.

İkinci olarak adına yolsuz tescil bulunan üçüncü kişinin bu davada TMK m. 713 uyarınca yirmi yıllık olağanüstü kazandırıcı zamanaşımı süresinin geçtiği gerekçesi ile taşınmazın mülkiyetini ya da irtifak hakkını (TMK m. 780/III’de yapılan yollama uyarınca) veya taşınmaz yükünü (TMK m. 840/III’de yapılan yollama uyarınca) kazandığını ileri sürmesi mümkündürr ${ }^{98}$. Zira öğretide mülkiyetin yolsuz tescil edilmiş olduğu hallerde, adına yolsuz tescil bulunan kişi bakımından olağanüstü kazandırıcı zamanaşımı yolu ile edinmenin mümkün olduğu kabul edilmektedir. $\mathrm{Bu}$ halde tapudaki kayıt yolsuz olduğundan gerçek maliki yansıtmamaktadır ${ }^{99}$. Olağanüstü kazandırıcı zamanaşımı ile kazanımın koşulları arasında üçüncü kişinin iyiniyetli olması koşulu da olmadığından, incelediğimiz ihtimalde önmirasçıdan taşınmazda hak elde eden iyiniyetli olmayan üçüncü kişi, taşınmaza davasız, aralıksız, yirmi yıl süreyle ve malik sıfatıyla zilyet olursa mülkiyeti kazanır. Dolayısıyla TMK m. 713’ün koşulları mevcutsa, artmirasçı üçüncü kişinin bu maddeye dayalı savunmasının önüne geçebilmek için, TMK m. 1025’e dayalı adi istihkak davası yerine, TMK m. 637’ye dayalı miras sebebiyle istihkak davası açmalıdır. Çünkü miras sebebi ile

96 Taşınmaz rehnini düzenleyen hükümlerde, hakkın kazanılması ve tescili ile ilgili taşınmaz mülkiyeti hükümlerine yollama yapılmadığından, taşınmaz rehninin olağan kazandırıcı zamanaşımı ile kazanılmasının mümkün olmadığına ilişkin Oğuzman/Seliçi/Oktay-Özdemir, N. 3251; Haab, Robert/Simonius, August/Scherrer, Werner/ Zobl, Dieter, Kommentar zum Schweizerischen Zivilgesetzbuch, Das Sachenrecht, ZK-Zürcher Kommentar, Band/ Nr. IV/1, Das Eigentum, Art. 641-729 ZGB, 2. Auflage, Zürich 1977, Art. 661-663, N. 3; Ertaş, N. 551; Sirmen, Eşya, s. 594-595.

97 Meier-Hayoz, Arthur, Berner Kommentar, Schweizeriches Zivilgesetzbuch, Das Sachenrecht, 1. Abteilung, Das Eigentum, 2. Teilband, Grundeigentum I, Artikel 655-679 ZGB, 3. Auflage, Bern 1969, Art. 661, N. 24; Oğuzman/Seliçi/Oktay-Özdemir, N. 1577; Esener/Güven, s. 240; Akipek/Akıntürk/Ateş, s. 485; Sirmen, Eşya, s. 361-362.

98 Taşınmaz rehnini düzenleyen hükümlerde, hakkın kazanılması ve tescili ile ilgili taşınmaz mülkiyeti hükümlerine yollama yapılmadığından, taşınmaz rehninin olağanüstü kazandırıcı zamanaşımı ile kazanılmasının mümkün olmadığına ilişkin Oğuzman/Seliçi/Oktay-Özdemir, N. 3251; Haab/Simonius/Scherrer/Zobl, Art. 661-663, N. 3; Ertaş, N. 551; Sirmen, Eşya, s. 594-595.

99 Eren, Fikret, Mülkiyet Hukuku, 4. Baskı, Ankara 2016, s. 290; Sirmen, Eşya, s. 368; Türk Medenî Kanunu m. 713 ’ün bu halde kıyasen uygulanacağı yönünde bkz. Gürsoy, Kemal T./Eren, Fikret/Cansel, Erol, Türk Eşya Hukuku, 2. Bas1, Ankara 1984, s. 533. 
istihkak davasında davalı, taşınmazı kazandırıcı zamanaşımı yoluyla kazandığını ileri süremez (TMK m. 638/II).

Bu hususların yanı sıra taşınmazı devralan üçüncü kişiye yapılan devir bakımından muvazaanın bulunması durumuna da değinilebilir ${ }^{100}$. Bu durumda devir ister mirasın artmirasçıya geçmesinden önce isterse bu andan sonra yapılsın, mirasın kendisine geçişi anı geldikten sonra artmirasçı üçüncü kişiye TMK m. 1025 uyarınca tapu sicilinin düzeltilmesi davası açarak taşınmazın adına tescilini talep edebilir ${ }^{101}$.

Buna karşılık önmirasçının taşınmazdaki tasarrufu üçüncü kişi lehine kişisel hakkın şerhi ise, bu hakkın TMK m. 1023 uyarınca korunması mümkün değildir. Türk Medenî Kanunu m. 1023'de açıkça aynî hak kazanımının korunmasına imkân tanınmıştır. Oysa kişisel hakkın şerhi, kişisel hakkın ileri sürülebileceği çevreyi genişletmekteyse de, hakkın niteliğinde bir değişiklik meydana getirmez. Bu nedenle şerh edilmiş kişisel hakkın kazanılması bakımından TMK m. 1023'e dayanılamamalıdır ${ }^{102}$. Şu halde mirasın geçiş anından sonra tapuda hâlâ yolsuz olarak malik gözüken önmirasçının yaptıracağı kişisel hakkın şerhine dayalı olarak üçüncü kişinin iyniyetinin korunması mümkün olmayıp, artmirasçının TMK m. 1025 uyarınca bu şerhin terkinini talep etmesi mümkündür. Örneğin mirasın geçiş anından sonra tapuda hâlâ yolsuz olarak malik gözüken önmirasçı, iyiniyetli üçüncü kişi ile taşınmaz satış vaadi yapar ve bu vaat tapuya şerh edilirse, kazanımı korunmayacağından ${ }^{103}$, üçüncü kişinin artmirasçıya TMK m. 716’ya dayalı dava açması halinde bu dava başarıya ulaşamamalıdır. Ayrıca bu durumda artmirasçı tarafından söz konusu şerhin terkini TMK m. 1025 ile sağlanabilir. Bunun aksine örneğin önmirasçı ile yaptı̆̆ı alım sözleşmesine dayalı olarak önmirasçıya karşı alım hakkını kullanan iyiniyetli üçüncü kişinin, henüz artmirasçı adına açıklayıcı tescil yapılmamışken taşınmazın mülkiyetini kazanmasında TMK m. 1023'e dayanılması mümkündür104.

100 Çabri, N. 699 dn. 1221, N. 708; Önmirasçının artmirasçıya geçirmekle yükümlü olduğu şeyleri muvazaalı bir şekilde elden çıkararak onu zarara uğratması durumunda TMK m. 2/I'deki hakkın kötüye kullanılması yasağının da ileri sürülebileceği yönünde görüş olarak bkz. İmre/Erman, s. 160.

101 Çabri, N. 708.

102 Oğuzman/Seliçi/Oktay-Özdemir, N. 1003 dn. 729; Ünal/Başpınar, s. 401; Ayan, Eşya, s. 236; Ertaş, N. 759; Breitschmid, Peter/Jungo, Alexandra (Hrsg.), CHK - Handkommentar zum Schweizer Privatrecht, Sachenrecht, Art. 641-977 ZGB, 3. Auflage, Zürich 2016 (Deillon-Schegg, Bettina), Art. 973, N. 12; Sirmen, Eşya, s. 200-201; Türk Medenî Kanunu m. 1023'de açıkça ortaya konulduğu üzere tapuya güven ilkesinin sadece aynî hakları koruma altına aldığına ilişkin bkz. Antalya, O. Gökhan/Topuz, Murat, Eşya Hukuku, Cilt III, Tapu Sicili, İstanbul 2018, s. 81; Aksi yönde tapu sicilinde yolsuz tescil sonucu malik gözüken kimsenin yaptıracağı kişisel hakkın şerhi bakımından TMK m. 1023’ün uygulanabileceği şeklinde görüş olarak bkz. Sungurbey, İsmet, Kişisel Hakların Tapu Kütüğüne Şerhi, İstanbul 1963, s. 132; Yakuppur, s. 28-29; Özçelik, s. 127-131.

103 Benzer örnek olarak bkz. Ertaş, N. 759.

104 Genel olarak yolsuz tescil sonucu tapuda malik gözüken kimse ile yapılan alım sözleşmesi bakımından aynı yönde örnek olarak bkz. Sirmen, Eşya, s. 201. 


\section{bb. Tapuda Artmirasçı Atanmasına ilişkin Şerhin Bulunması}

Tapuda artmirasçı atanmasına ilişkin şerh varsa, şerhten sonra tapu sicilinin kapanması/ kilitlenmesi söz konusu olmamalıdır. Ama mirasın geçiş anının gelmesi ile artmirasçı tescile gerek olmadan malik olduğu için, bu aşamada taşınmazda önmirasçıdan aynî hak elde eden kimsenin kazanımı yolsuz tescil olur. Şerhin varlığı karşısında, üçüncü kişinin iyiniyet iddiasında bulunması da mümkün olamayacağına göre, aynî hak kazanımının TMK m. 1023 anlamında korunmasından söz edilemez. Şerhe rağmen hakkı kazanan üçüncü kişi, mirasın artmirasçıya geçişi anı geldiğinde hakkının o an itibarıyla sona ermesine TMK m. 1010/II uyarınca katlanmak zorundadır. Bu durumda gerçek malik artmirasçı, tapuda malik görünen üçüncü kişiye yönelteceği ister TMK m. 1025’e dayalı adi istihkak davası isterse TMK m. 637’ye dayalı miras sebebiyle istihkak davası ile taşınmazın kendi adına tescilini; üçüncü kişinin hakkı bir sınırlı aynî hak ise bu hakkın terkin edilerek taşınmazın kendi adına tescilini isteyebilir.

\section{Artvasiyet Alacaklısı Atama Tasarrufu Bakımından}

\section{a. Vasiyetin Artvasiyet Alacaklısına Geçirilmesi Gereken Andan Önceki Aşama}

\section{aa. Tapuda Artvasiyet Alacaklısı Atanmasına ilişkin Şerhin Bulunmaması}

Tapuda artvasiyet alacaklısı atanmasına ilişkin şerh yoksa, bu aşamada önvasiyet alacaklısı, vasiyet konusu taşınmaz üzerinde tasarruf yetkisine tam olarak sahip olduğundan taşınmaz üzerinde yaptığı tasarruflar (örneğin taşınmazı üçüncü bir kişiye devretmesi, taşınmazda üçünü kişi lehine sınırlı aynî hak kurması veya kişisel hakları şerh vermesi) geçerlidir. Bu durumda tıpkı önmirasçıda olduğu gibi, devir yükümlülüğünü tamamen ya da kısmen yerine getiremeyen önvasiyet alacaklısı, artvasiyet alacaklısının olumlu zararını, TMK m. 5 hükmünde yapılan yollama gereğince TBK m. 112 hükmüne dayalı olarak tazmin edecektir. Ayrıca artvasiyet alacaklısının, önvasiyet alacaklısının vasiyet konusu taşınmazı teslim almasının bir koşulu olarak gösterdiği güvencelere başvurma imkânı da bulunmaktadır.

\section{bb. Tapuda Artvasiyet Alacaklısı Atanmasına Iliş̧kin Şerhin Bulunması}

Tapuda artvasiyet alacaklısı atanmasına ilişkin şerh varsa ve önvasiyet alacaklısı şerhe rağmen taşınmazda üçüncü kişi lehine tasarruf ederse (örneğin taşınmazı üçüncü bir kişiye devreder, taşınmazda üçüncü kişi lehine sınırlı aynî hak kurar veya kişisel hakkı şerh verirse), geçiş anı geldiğinde yapılan bu devir artvasiyet alacaklısına karşı ileri sürülemez ve artvasiyet alacaklısı taşınmazın kendisine devredilmesini üçüncü kişiden isteyebilir. Bu durumda TMK m. 1010/II dolayısıyla artvasiyet alacaklısının hakkını doğrudan üçüncü kişiye karşı ileri sürebileceği sonucuna ulaşılır. Şerhten sonra hak kazananlar kendi adlarına 
yapılmış olan tescilin terkinine ve taşınmazın artvasiyet alacaklısı adına tesciline katlanmak zorunda kalacaktır ${ }^{105}$.

\section{b. Vasiyetin Artvasiyet Alacaklısına Geçirilmesi Gereken Andan Sonraki Aşama}

Daha önce açıklandığı üzere ${ }^{106}$ vasiyetin geçişi anı geldiğinde, artmirasçının aksine, artvasiyet alacaklısı taşınmazın mülkiyetini kendiliğinden kazanmadığı için, tapudaki tescilin yolsuzlaştı̆̆ söylenemez. Bu aşamada da önmirasçının yaptığı tasarruf işleminin geçerliliği bakımından, işlem anında tapuda artvasiyet alacaklısı atanmasına ilişkin şerhin bulunup bulunmamasına göre farklı sonuçlara varılır.

\section{aa. Tapuda Artvasiyet Alacaklısı Atanmasına Ilişkin Şerhin Bulunmaması}

Tapuda artvasiyet alacaklısı atanmasına ilişkin şerh yoksa, vasiyetin geçiş anının gelmesinden sonra, henüz artvasiyet alacaklısına devir yapılmamışken, önvasiyet alacaklısı taşınmazda üçüncü kişiye hak sağlarsa - örneğin taşınmazı üçüncü kişiye devreder, taşınmazda sınırlı aynî hak kurar veya kişisel hakları şerh verirse-, bir defa aynî haklar bakımından TMK m. 1023 hükmünün uygulanmasına yer olmadığı belirtilmelidir. Çünkü geçiş anı geldiğinde artvasiyet alacaklısı malik olmadığı, yalnızca vasiyet alacağı kazandığı için, bu aşamada önvasiyet alacaklısından vasiyet konusu taşınmazda aynî hak edinen üçüncü kişinin güvendiği tescil yolsuz değildir. Dolayısıyla yapılan devir geçerli olur. Aynı şekilde bu aşamada yapılan kişisel hakkın şerhinin de geçerli olduğu sonucuna varılmalıdır. Yani bu aşamada önvasiyet alacaklısının taşınmazı devretmesi hâlinde, artvasiyet alacaklısı taşınmazın aynına kavuşamayacak; önvasiyet alacaklısının sınırlı aynî hak kurması ya da kişisel hakkı şerh vermesi halinde ise, artvasiyet alacaklısı taşınmazın kendi adına tescilini sağladığında, taşınmazı söz konusu sınırlı aynî hak ile ya da kişisel hakkın şerhi ile yüklü olarak kazanacaktır. Bu şekilde üçüncü kişinin kazanımının geçerli olması sonucunda miras kapsamında yer alan taşınmaza hiç ya da olması gerektiği şekilde kavuşamayan artvasiyet alacaklısının elindeki imkân ise, olumlu zararının tazminini, TMK m. 5 hükmünde yapılan yollama gereğince TBK m. 112 hükmüne dayalı olarak önvasiyet alacaklısından istemektir. Zira önvasiyet alacaklısı, kanundan doğan mirası artvasiyet alacaklısına geçirme yükümlülügünü (TMK m. 521/I, III) gereği gibi yerine getirmemiştir. Bu hususta artvasiyet alacaklısının, önvasiyet alacaklısının vasiyet konusu taşınmazı teslim almasının bir koşulu olarak gösterdiği güvencelere başvurma imkânı da bulunmaktadır.

Ayrıca vasiyetin geçiş anı gelmesine rağmen kendi rızası ile devri gerçekleştirmeyen önvasiyet alacaklısına yöneltilmiş dava (TMK m. 716) sürerken de taşınmazın önvasiyet alacaklısı tarafından üçüncü kişiye devredilmesi mümkündür. Bu durum davalı tarafından dava konusunun devri niteliğindedir ve bu hususta HMK m. 125/(1) hükmündeki düzenleme de devreye girebilir. Hukuk Muhakemeleri Kanunu m. 125/(1), a bendinin ifadesi “isterse devreden tarafla olan

105 Aynı yönde Çabri, N. 723; Doğan, s. 186.

106 Bkz. Başlık I., B. 
davasından vazgeçerek, dava konusunu devralmış olan kişiye karşı davaya devam eder" şeklindedir. Ancak hükmün lafzı yanıltıcı olmamalıdır. Şöyle ki; bu hüküm uyarınca her durumda artvasiyet alacaklısının davasına, dava konusu taşınmazı devralan üçüncü kişiye karşı devam edebileceği düşünülemez. Zira artvasiyet alacaklısının sahip olduğu hak bir alacak hakkı olması sebebi ile kişisel (şahsi, nisbî) haktır. Borç ilişkisinin nisbîliği uyarınca HMK m. 125/(1), a bendinin gereği olarak davacı artvasiyet alacaklısının, davasını taşınmazı devralan üçüncü kişiye yöneltmesi mümkün değildir. Hukuk Muhakemeleri Kanunu m. 125/(1), a bendinin varlı̆̆ı, özel hukukun hüküm ve sonuç bağladığı olguları ve bu olgulara bağlı hak kazanımlarını ortadan kaldıramaz. Bu gerekçe ile artvasiyet alacaklısı tarafından önvasiyet alacaklısına karşı açılmış TMK m. 716'ya dayalı davada hâkimin takdir hakkı ile TMK m. 1010/b.1 uyarınca çekişmeli hakların korunması şerhi ${ }^{107}$ verilmelidir. Bu şerh verilmedikçe davalı önvasiyet alacaklısı üçüncü kişiye taşınmaz üzerinde aynî hak kazandıracak olursa, HMK m. 125/(1), a bendinin uygulanmasından söz edilemez. Çünkü borç ilişkisinin nisbîliği gereği üçüncü kişi borç ilişkisine taraf değildir ve bu ilişkiyi ihlâl edemez ${ }^{108}$. Eğer hâkim tarafından TMK m. 1010/b. 1 uyarınca çekişmeli hakların korunması şerhi konulmuş ve üçüncü kişiye dava konusunun devri bu andan sonra gerçekleşmiş ise artık eşyaya bağlı borç etkisi ile HMK m. 125/(1), a bendinin uygulanması ve davanın üçüncü kişiye karşı devam ettirilmesi mümkün olur. Zira artık taşınmazı yeni edinen üçüncü kişi, davalı önvasiyet alacaklısının halefi olarak onun borcunun yükümlüsüdür. Bu halde HMK m. 125/ (1), a bendinin uygulanması sonucunda davalı sıfatı (pasif husumet) artık, eşyaya bağlı borcun yükümlüsü olan yeni edinen halefte, yani önvasiyet alacaklısından taşınmazı devralan kişidedir.

Yine tapuda artvasiyet alacaklısı atanmasına ilişkin şerh bulunmamakla birlikte, üçüncü kişiye yapılan devir sırasında TBK m. 49/II'nin koşulları varsa, taşınmazı devralan üçüncü kişiye TMK m. 716 uyarınca dava açılması mümkün olur. Örneğin önvasiyet alacaklısından taşınmazı devralan üçüncü kişi, artvasiyetten haberdar olmasına rağmen, sübjektif nedenlerle sırf artvasiyet alacaklısının taşınmaza kavuşamaması için, kendi ihtiyacı olmamasına rağmen, ahlâka aykırı bir fiille taşınmazın mülkiyetini edinirse, salt bu fiil TBK m. 49/II anlamında bir haksız fiil oluşturur ve zararı tazmin borcu doğar. Bu ihtimalde artvasiyet alacaklısının mahkemeden TMK m. 716 uyarınca taşınmazın mülkiyetinin hükmen geçirilmesini istemesi mümkündür. Zira hâkim TBK m. 49/II’ye dayalı olarak açılan davada TBK m. 51/I uyarınca sahip olduğu takdir hakkına bağlı olarak zararın aynen tazminine hükmedecek olursa, kıyasen TMK m. 716’ya dayalı olarak mülkiyetin hükmen geçirilmesine karar verebilecektir ${ }^{109}$.

107 Oysa uygulamada bu hüküm gereği şerh verilmeyip HMK m. 389 uyarınca tapu kütüğünü kilitleyen ihtiyati tedbir kararları (HMK m. 389/I) verilmektedir. Bu durumda ise davalının zaten taşınmazda tasarruf etmesi mümkün olmadığından HMK m. 125/(1), a bendinin uygulanmasını gerektiren bir olasılık söz konusu olamamaktadır.

108 Genel olarak tescilli isteme davasında dava konusunun devrine ilişkin olarak bkz. Özmen/Aydın, s. 202.

109 Genel olarak haksız fiilden doğan alacak hakkına dayalı tescile zorlama davaları hakkında aynı yönde görüş olarak bkz. Özmen/Aydın, s. 195-197; Türk Borçlar Kanunu m. 49/II’nin koşulları varsa, şerh bulunmadığı için yapılan devrin geçerli olduğu sonucuna varılamayacağı yönünde bkz. Çabri, N. 699 dn. 1221. 


\section{bb. Tapuda Artvasiyet Alacaklısı Atanmasına ilişkin Şerhin Bulunması}

Tapuda artvasiyet alacaklısı atanmasına ilişkin şerh varsa, vasiyetin geçiş anı geldikten sonra, artvasiyet alacaklısına devir yapılmadan önce, önvasiyet alacaklısı taşınmazda üçüncü kişiye hak sağladığında (örneğin taşınmazın üçüncü kişiye devri, taşınmazda sınırlı aynî hak kurulması veya kişisel hakların şerh verilmesi), TMK m. 1010/II uyarınca artvasiyet alacaklısı hakkını doğrudan üçüncü kişiye karşı TMK m. 716’ya dayalı dava açarak ileri sürebilir.

\section{Bakiye Üzerine Artmirasçı Atama Tasarrufu Bakımından}

Bakiye üzerinde artmirasçılıkta artmirasçıya, önmirasçının kullanım ve tüketiminden kalacak bakiyeye sahip olma şeklinde bir hak tanınmaktadır. Bu halde önmirasçı, mirasın geçiş anı geldiğinde geriye ne kald ${ }_{1}$ ise yalnızca onu artmirasçıya devretmekle yükümlü olur ${ }^{110}$. Bu nedenle bakiye üzerinde artmirasçllıkta güvence verilmesi söz konusu olmamaktadır ${ }^{111}$.

$\mathrm{Bu}$ tür mirasçılıkta önmirasçının miras kapsamında yer alan eşyalar - çalışma özelinde taşınmazlar - üzerinde sahip olduğu tasarruf yetkisinin kapsamı belirlenirken söz konusu ölüme bağlı tasarrufa bakılması gerekir. Eğer ölüme bağlı tasarrufun yorumundan, mirasbırakanın önmirasçıya bir sınır getirmeden tasarruf yetkisi tanıdı̆̆ı sonucuna varılıyorsa, artmirasçının önmirasçıdan bir talepte bulunması mümkün olmaz ${ }^{112}$. Yine de önmirasçının bu eşyalara ilişkin ölüme bağlı tasarrufta bulunmasının ya da alışılmış ölçüyü aşan bağışlama yapmasının vasiyette bulunanın amacına aykırı olacağı belirtilmektedir ${ }^{113}$. Buna karşılık mirasbırakanın önmirasçının tasarruf yetkisine sinırlama getirmesi de mümkündür. Bu durumda önmirasçı söz konusu sınırlamanın dışına çıkacak bir tasarrufta bulunursa artmirasçı haklarının tehlikeye düştüğü oranda terekenin resmen yönetilmesini isteyebilir ${ }^{114}$.

110 Escher/Escher, Vorbem. Art. 488-493, N. 11; Oğuzman, s. 155 dn. 336; İmre/Erman, s. 160; Dural/Öz, N. 812; Hrubesch-Millauer, Art. 488, N. 13; Studhalter, Art. 488, N. 1; “... Bunun için murisin davacıya hem dilediği şekilde tasarruf etmek yetkisi vermiş olması ve hem de teminat göstermekten onu muaf tutmuş bulunması nedeniyle davacının ölümünden sonra davalıya intikal edecek mirasın bir nevi bakiye miras olarak düşünüldüğü açıkça anlaşılmaktadır....", Yarg. HGK., 10.11.1982, E. 1981/2-77, K. 1982/881, legalbank.net (1.04.2019).

111 Escher/Escher, Vorbem. Art. 488-493, N. 11; Oğuzman, s. 155 dn. 336; Dural/Öz, N. 812; Hrubesch-Millauer, Art. 488, N. 13; Studhalter, Art. 490, N. 3.

112 Escher/Escher, Vorbem. Art. 488-493, N. 11; İmre/Erman, s. 160-161; Dural/Öz, N. 812; Hrubesch-Millauer, Art. 488, N. 13; Çabri, N. 710, N. 715.

113 Oğuzman, s. 155 dn. 336; Hrubesch-Millauer, Art. 488, N. 14; Bu durumda TMK m. 2/II'deki hakkın kötüye kullanılması yasağının da ileri sürülebileceği görüşü için bkz. Escher/Escher, Vorbem. Art. 488-493, N. 11; İmre, s. 211; İmre/Erman, s. 161; İșgüzar/Demir/Yılmaz, s. 71; “... Ön mirasçının, murisin vasiyetnamesi ile amaçladı̆̆ hususların gerçekleşmesini tamamen ortadan kaldıracak nitelikte temliki tasarrufta bulunması halinde, iyiniyetle telif olunamıyacak bu tasarruflar için elbette davalının Medeni Kanunun 2. maddesine göre hak arayabileceğinin kabul edilmesi gerekir. Ancak, olayda henüz gerçekleşmiş böylesine bir tasarrufun bulunmadığı anlaşılmaktadır. Bu itibarla, davalının davacının tasarrufuna engel teşkil edecek biçimde iddia ile tedbir alması ve bunu uygulamaya koyması haksız bir davranış ve kanuna aykırı bir muamele teşkil eder. ...", Yarg. HGK., 10.11.1982, E. 1981/2-77, K. 1982/881, legalbank.net (1.04.2019).

114 Çabri, N. 710. 


\section{SONUÇ}

Çalışma çerçevesinde önmirasçının miras kapsamında yer alan taşınmaza ilişkin yaptığı sağlararası tasarruf işlemlerinin geçerli olup olmadığı hakkında şu tespitlere varılmıştır:

I. Önmirasçı, mirasbırakanın ölmesi ile ilk sırada mirasçılık sıfatını atanmış mirasçı gibi kazanır. Ancak önmirasçı, geçiş anı olarak belirlenen vade geldiğinde ya da koşul gerçekleştiğinde bu mirası artmirasçıya geçirme yükümlülüğü altındadır.

II. Türk Medenî Kanunu m. 523/II uyarınca mirasın önmirasçıya teslimi, önmirasçının güvence göstermesine bağlanmıştır. Hükmün lafzı güvencenin belirlenmesi bakımından seçim hakkının önmirasçıda olduğuna yöneliktir. Oysa kanımızca kural olarak artmirasçı atamada önmirasçı her türlü güvenceyi gösterebilirse de, artmirasçının talep etmesi halinde tapu siciline şerh yoluna başvurulmalıdır. Ayrıca de lege ferenda bir öneri olarak kanunda güvencenin çeşidi bakımından tercih özgürlüğü artmirasçıya bırakılmalı ve şerhin yanı sıra başka güvencelerin de gösterilebilmesine açıkça imkân tanınmalıdır.

III. Miras kapsamında yer alan taşınmazların mülkiyetinin artmirasçıya geçişi, geçiş anının gelmesi ile birlikte kendiliğinden ve kanun gereği olur. Bu bir tescilsiz kazanma halidir.

IV. Önmirasçı mirasın artmirasçıya geçişi anına kadar, miras kapsamında yer alan taşınmazda mülkiyet hakkı sahibi olarak yönetim yetkisi kapsamında zorunlu tasarrufları yapabilir. Bunun dışında önmirasçının tasarruf yetkisinin kısıtlı olup olmadığı konusunda Türk Medenî Kanunu’nda açık bir hüküm bulunmamakta olup, konu öğretide tartışmalıdır. Kanımızca en ideal olan bu hususun kanun koyucu tarafından düzenlenmesi ve öğretide ileri sürülen görüşlerden birinin kanunda açıkça benimsenmesidir. Biz bu hususta önmirasçının tasarruf yetkisinin kısıtlı olmadığını kabul eden görüşün, vardığı sonuçları itibarıyla gerek hukukun ilkeleri gerekse Türk Borçlar Kanunu ve Türk Medenî Kanunu’nun sistemi ile daha uyumlu olduğu kanaatindeyiz. Katıldığımız görüş ışı̆̆ında önmirasçının tasarrufları bakımından vardığımız sonuçları kısaca özetlemek gerekirse;

A. Önmirasçı mirasın artmirasçıya geçişi anından önce taşınmazı konu alan bir tasarruf işlemi yaparsa ve tapuda artmiraş̧ı atanmasına ilişkin şerh yoksa, önmirasçının yaptığı tasarruf geçerlidir. Artmirasçının mirasın geçiş anı geldiğinde, o anda önmirasçının mülkiyetinde olmayan bir taşınmazı küllî halefiyet yolu ile kazandığından söz edilemez. Tapuda artmiraş̧ı atanmasına ilişkin şerhin olduğu durumda ise, şerhin varlığı önmirasçının tasarruf yetkisini kısıtlamaz. Şerhten sonra hak kazanan kişi, mirasın artmirasçıya geçişi anı geldiğinde hakkının o an itibarıyla sona ermesine TMK m. 1010/II uyarınca katlanır. Bu aşamada önmirasçının yaptığ tasarruflar bakımından TMK m. 1023 hükmünün herhangi bir uygulanma alanı yoktur. Çünkü önmirasçının adına tapuda görünen tescil yolsuz bir tescil değildir.

B. Önmirasçı mirasın artmirasçıya geçişi anından sonra taşınmazı konu alan bir tasarruf işlemi yaparsa ve tapuda artmirasçı atanmasına ilişkin şerh yoksa, iyiniyetli üçüncü kişi TMK m. 
1023 uyarınca aynî hakkı kazanır. Bu durumda HMK m. 125/(1), a bendinin uygulanmasına da yer yoktur. Buna karşılık üçüncü kişi iyiniyetli değil ise, geçiş anının gelmesi ile artmirasçı mülkiyeti kazanır ve üçüncü kişiye karşı açacağı TMK m. 1025’e dayalı tapu sicilinin düzeltilmesi davası ile taşınmazın adına tescilini sağlar. Üçüncü kişiye yapılan devir TMK m. 1025’e dayalı dava sürerken de gerçekleştirilebileceğinden, TMK m. 1011/I, b. 1 uyarınca geçici tescil şerhi konulması önemlidir. Böylece şerhten sonra dava konusu taşınmaz üçüncü kişiye devredilirse, şerhe rağmen devralan üçüncü kişinin iyiniyetli olmadığı kolaylıkla ispatlanacağından, HMK m. 125/(1), a bendi uyarınca davanın üçüncü kişiye karşı devam ettirilmesi mümkün olacaktır. Tapuda artmirasçı atanmasına ilişkin şerhin olduğu durumda ise, şerhin varlığı karşısında üçüncü kişinin kazanımının TMK m. 1023 uyarınca korunması mümkün olmaz ve üçüncü kişi kendi adına olan tescilin yolsuzlaşmasına TMK m. 1010/II uyarınca katlanır.

C. Önvasiyet alacaklısı vasiyetin geçişi anından önce taşınmazı konu alan bir tasarruf işlemi yaparsa ve tapuda artvasiyet alacaklısı atanmasına ilişkin şerh yoksa önvasiyet alacaklısının yaptığı tasarruf işlemi geçerlidir. Tapuda artvasiyet alacaklısı atanmasına ilişkin şerhin olduğu durumda ise, geçiş anı geldiğinde yapılan devir artvasiyet alacaklısına karşı ileri sürülemez ve artvasiyet alacaklısı taşınmazın kendisine devredilmesini TMK m. 1010/II uyarınca üçüncü kişiden isteyebilir.

D. Önvasiyet alacaklısı vasiyetin geçişi anından sonra taşınmazı konu alan bir tasarruf işlemi yaparsa ve tapuda artvasiyet alacaklısı atanmasına ilişkin şerh yoksa aynî haklar bakımından TMK m. 1023'ün uygulanması söz konusu olmaz. Zira geçiş anı geldiğinde artvasiyet alacaklısı malik olmadığı, yalnızca vasiyet alacağı kazandığı için, önvasiyet alacaklısı adına olan tescil yolsuz değildir. Artvasiyet alacaklısı tarafından önvasiyet alacaklısına karşı açılan TMK m. 716'ya dayalı dava sürerken devrin gerçekleştirilmesi halinde ise, dava sırasında TMK m. 1010/b. 1 uyarınca çekişmeli hakların korunması şerhi verilmedikçe borç ilişkisinin nisbîliği uyarınca HMK m. 125 hükmünün gereği olarak davacı artvasiyet alacaklısının davasını dava konusunu devralan üçüncü kişiye yöneltmesi mümkün olmaz. Tapuda artvasiyet alacaklısı atanmasına ilişkin şerhin olduğu durumda ise, TMK m. 1010/II uyarınca artvasiyet alacaklısının hakkını doğrudan üçüncü kişiye karşı ileri sürebilmesi ve TMK m. 716 uyarınca davanı üçüncü kişiye karşı açabilmesi mümkündür.

E. Önmirasçı ya da önvasiyet alacaklısı mirası geçirme yükümlülügüüü tamamen veya kısmen yerine getiremezse, artmirasçının ya da artvasiyet alacaklısının olumlu zararını, TMK m. 5 hükmünde yapılan yollama gereğince TBK m. 112 hükmüne dayalı tazmin etmek durumunda kalır. Zira bu durumda önmirasçı ya da önvasiyet alacaklısı kanundan doğan mirası geçirme yükümlülügünü (TMK m. 521/I, III) gereği gibi yerine getirememiştir. 


\section{KISALTMALAR}

Art. : Artikel

b. : bent

bkz. : bakınız

BSK : Basler Kommentar

C. $\quad$ : Cilt

CHK : Hand Kommentar zum Schweizer Privatrecht

dn. : dipnot

E. : Esas

HD : Hukuk Dairesi

HGK : Hukuk Genel Kurulu

HMK : 6100 sayılı Hukuk Muhakemeleri Kanunu

Hrsg. : Herausgegeben

K. : Karar

m. : madde

N. : Kenar Numarasi

OFK : Orell Füssli Kommentar

OR : Schweizerisches Obligationenrecht (İsviçre Borçlar Kanunu)

s. : : sayfa

S. $\quad$ : Say1

$\$ \quad$ : Paragraf

TBK : 6098 sayılı Türk Borçlar Kanunu

TMK : : 4721 sayılı Türk Medenî Kanunu

TST : Tapu Sicil Tüzüğü

vd. : ve devamı

Vorbem. : Vorbemerkungen

Yarg. : Yargitay

ZGB : Schweizerisches Zivilgesetzbuch (İsviçre Medenî Kanunu) 


\section{KAYNAKÇA}

Akbıyı, Cem, Miras Sebebiyle İstihkak Davası, İstanbul 2003.

Akipek, Jale/Akıntürk, Turgut/Ateş, Derya, Eşya Hukuku, 2. Baskı, İstanbul 2018.

Antalya, O. Gökhan/Sağlam, İpek, Miras Hukuku, 3. Baskı, İstanbul 2015.

Antalya, O. Gökhan/Topuz, Murat, Eşya Hukuku, Cilt III, Tapu Sicili, İstanbul 2018.

Ayan, Mehmet, Miras Hukuku, 9. Baskı, Ankara 2016.

Ayan, Mehmet, Eşya Hukuku I, Zilyetlik ve Tapu Sicili, 13. Baskı, Ankara 2016 (Eşya).

Aybay, Aydın/Hatemi, Hüseyin, Eşya Hukuku, 4. Bası, İstanbul 2014.

Ayiter, Nuşin, Miras Hukuku, 4. Bası, Ankara 1978.

Belgesay, Mustafa Reşit, Türk Kanunu Medenisi Şerhi, Üçüncü Kitap, Miras, 4. Baskı, İstanbul 1952.

Börï, Levent, Dava Konusunun Devri, Ankara 2012.

Breitschmid, Peter/Jungo, Alexandra (Hrsg.), Handkommentar zum Schweizer Privatrecht, Erbrecht, Art. 457-640 ZGB, 3. Auflage, Zürich 2016 (Hrubesch-Millauer, Stephanie).

Breitschmid, Peter/Jungo, Alexandra (Hrsg.), CHK - Handkommentar zum Schweizer Privatrecht, Sachenrecht, Art. 641-977 ZGB, 3. Auflage, Zürich 2016 (Deillon-Schegg, Bettina).

Çabri, Sezer, Miras Hukuku Şerhi (TMK m. 495-574) Cilt - I, 1. Baskı, İstanbul 2018.

Doğan, Murat, Tapu Sicilinde Tasarruf Yetkisi Kısıtlamasının Şerhi, Ankara 2004.

Dural, Mustafa/Öz, Turgut, Türk Özel Hukuku, Cilt IV, Miras Hukuku, 12. Bası, İstanbul 2018.

Eren, Fikret, Mülkiyet Hukuku, 4. Baskı, Ankara 2016.

Eren, Fikret/Yücer Aktürk, İpek, Türk Miras Hukuku, Ankara 2019.

Ertaş, Şeref, Eşya Hukuku, 13. Baskı, İzmir 2017.

Escher, A./Escher, Arnold, Kommentar zum Schweizerischen Zivilgesetzbuch, Das Erbrecht, III. Band, Erste Abteilung: Die Erben (Art. 457-536), Zürich 1959.

Esener, Turhan/Güven, Kudret, Eşya Hukuku, 7. Baskı, Ankara 2017.

Gönensay, Samim/Birsen, Kemaleddin, Miras Hukuku, İstanbul 1956.

Gümüş, Mustafa Alper, Türk Medenî Kanununun Getirdiği Yeni Şerhler, İstanbul 2007.

Gürpınar, Damla, Artmirasçı Atama, Ankara 2018.

Gürsoy, Kemal Tahir, Türk Medenî Kanunu Hükümlerine Göre Mal Vasiyeti, Ankara 1955.

Gürsoy, Kemal T./Eren, Fikret/Cansel, Erol, Türk Eşya Hukuku, 2. Bası, Ankara 1984.

Haab, Robert/Simonius, August/Scherrer, Werner/Zobl, Dieter, Kommentar zum Schweizerischen Zivilgesetzbuch, Das Sachenrecht, ZK-Zürcher Kommentar, Band/Nr. IV/1, Das Eigentum, Art. 641-729 ZGB, 2. Auflage, Zürich 1977.

Hatemi, Hüseyin, Miras Hukuku, 8. Bası, İstanbul 2018.

Hatemi, Hüseyin/Serozan, Rona/Arpacı, Abdülkadir, Eşya Hukuku, İstanbul 1991.

Hausheer, Heinz/Walter, Hans Peter (Hrsg.), Berner Kommentar, Schweizerisches Zivilgesetzbuch, Das Erbrecht, Band III, 1. Abteilung, Die Erben, 1. Teilband, 1. Teil, Art. 457-516 ZGB, Bern 2009 (Weimar, Peter).

Homberger, A., Kommentar zum Schweizerischen Zivilgesetzbuch, IV. Band: Sachenrecht, 3. Abteilung, Besitz und Grundbuch, Art. 919-977, 2. Auflage, Zürich 1938.

Honsell, Heinrich/Vogt, Nedim Peter/Geiser, Thomas (Hrsg.), Basler Kommentar, Zivilgesetzbuch II, Art. 457-977 ZGB, Art. 1-61 SchlT ZGB, 3. Auflage, Basel/Genf/München 2007.

İmre, Zahit, Türk Miras Hukuku, 3. Bası, 1972. 
İmre, Zahit/Erman, Hasan, Miras Hukuku, 14. Basım, İstanbul 2018.

İnan, Ali Naim/Ertaş, Şeref/Albaş, Hakan, Türk Medeni Hukuku Miras Hukuku, 10. Bası, Ankara 2019.

İşgüzar, Hasan/Demir, Mehmet/Yılmaz, Süleyman, Miras Hukuku, Ankara 2019.

Kılıçoğlu, Ahmet, Miras Hukuku, 8. Bası, Ankara 2018.

Kocayusufpaşaoğlu, Necip, Miras Hukuku, 3. Bası, İstanbul 1987.

Kostkiewicz, Jolanta Kren/Wolf, Stefan/Amstutz, Marc/Fankhauser, Roland (Hrsg.), ZGB Kommentar Schweizerisches Zivilgesetzbuch, OFK-Orell Füssli Kommentar, 3. Auflage, Zürich 2016 (Studhalter, Philipp).

Köprülü, Bülent, Miras Hukuku Dersleri, 2. Bası, İstanbul 1985.

Meier-Hayoz, Arthur, Berner Kommentar, Schweizeriches Zivilgesetzbuch, Das Sachenrecht, 1. Abteilung, Das Eigentum, 2. Teilband, Grundeigentum I, Artikel 655-679 ZGB, 3. Auflage, Bern 1969.

Nomer, Halûk N., Beklenen Haklar Üzerindeki Tasarrufların Hukukî Sonuçları, İstanbul 2002.

Nomer, Halûk Nami/Ergüne, Serkan, Eşya Hukuku, 6. Bası, İstanbul 2019.

Oğuzman, M. Kemal, Miras Hukuku, 6. Bası, İstanbul 1995.

Oğuzman, M. Kemal/Seliçi, Özer/Oktay-Özdemir, Saibe, Eşya Hukuku, 21. Baskı, İstanbul 2018.

Özçelik, Ş. Barış, Tapu Siciline Güvenin Korunması, Ankara 2016.

Özmen, Etem Sabâ/Aydın, Gülşah Sinem, “Tapu İptal Davası Olarak Yanlış Adlandırma ile Açılan Davalar (Tescili İsteme Davası/Yolsuz Tescilin Düzeltilmesi Davası)", İstanbul Barosu Dergisi, C. 88, S. 2014/6, (s. 179-215).

Öztan, Bilge, Miras Hukuku, 9. Baskı, Ankara 2018.

Piotet, Paul, Schweizerisches Privatrecht, Vierter Band, Erbrecht, Erster Halbband, Basel 1978.

Saymen, Ferit H., Miras Hukuku Dersleri, İstanbul 1955.

Serozan, Rona/Engin, Baki İlkay, Miras Hukuku, 5. Baskı, Ankara 2018.

Sirmen, Lâle, Türk Özel Hukukunda Şart, Ankara 1992.

Sirmen, Lâle, Eşya Hukuku, 6. Baskı, Ankara 2018 (Eşya).

Sungurbey, İsmet, Kişisel Hakların Tapu Kütüğüne Şerhi, İstanbul 1963.

Tekinay, Selâhattin Sulhi/Akman, Sermet/Burcuoğlu, Halûk/Altop, Atilla, Tekinay Eşya Hukuku, Cilt I, İstanbul 1989.

Tuor, Peter/Schneyder, Bernhard/Schmid, Jörg/Rumo-Jungo, Alexandra, Das Schweizerische Zivilgesetzbuch, 13. Auflage, Zürich-Basel-Genf 2009 (Tuor, Peter).

Ünal, Mehmet/Başpınar, Veysel, Şeklî Eşya Hukuku, 9. Baskı, Ankara 2017.

Vardar Hamamcıŏglu, Gülşah, Medenî Hukuk’ta Tasarruf İşlemi Kavramı, İstanbul 2014.

Yakuppur, Sendi, Tapu Kütüğüne Güven İlkesi, İstanbul 2016.

\section{Veri Tabanları:}

legalbank.net

https://emsal.yargitay.gov.tr.

www.swisslex.ch/ 